\title{
Porous Silicon-Based Catalysts for the Dehydration of Glycerol to High Value-Added Products
}

\author{
Juan Antonio Cecilia (iD, Cristina García-Sancho *, Carmen Pilar Jiménez-Gómez, \\ Ramón Moreno-Tost and Pedro Maireles-Torres \\ Universidad de Málaga, Departamento de Química Inorgánica, Cristalografía y Mineralogía (Unidad Asociada \\ al ICP-CSIC), Facultad de Ciencias, Campus de Teatinos s/n, 29071 Málaga, Spain; jacecilia@uma.es (J.A.C.); \\ carmenpjg@uma.es (C.P.J.-G.); rmtost@uma.es (R.M.-T.); maireles@uma.es (P.M.-T.) \\ * Correspondence: cristinags@uma.es; Tel.: +34-952132373; Fax: +34-952131870
}

Received: 29 June 2018; Accepted: 27 August 2018; Published: 31 August 2018

\begin{abstract}
Increasing worldwide biodiesel production has led to the generation of an important glycerol surplus, which needs to be valorized in order to improve the economic and environmental sustainability of the biodiesel industry. In this context, glycerol dehydration to acrolein by acid catalysis appears to be a potential route of glycerol valorization, since acrolein is an important intermediate for many chemical industries. The main drawback of this catalytic process is catalyst deactivation. Different alternatives have been proposed for overcoming it, such as the use of mesoporous materials in order to facilitate the diffusion of glycerol and reaction products, thus minimizing deactivation. This review compiles the main achievements of the use of mesoporous silica-containing materials that have been deployed either as a catalyst or for support in glycerol dehydration to acrolein. Thus, the effect of mesoporosity on both catalytic performance and deactivation will be discussed, as well as the blocking of pores by coke deposition.
\end{abstract}

Keywords: mesoporous silica; glycerol; dehydration; acid catalysis; acrolein

\section{Introduction}

The growth of the world population, as well as improvement in quality of life, have caused an exponential consumption of fossil resources in the last century. This has led to their depletion, so it the search and development of alternative energy sources to replace them efficiently is necessary. Among them, biomass is the only sustainable source from which energy, fuels, and chemicals can be obtained [1]. Currently, the governments are legislating stringent regulations in which traditional fuels must be blended with biofuels in order to decrease emissions associated with fossil fuels. In this regard, the European Union aims to have $10 \%$ of the transport fuel coming from renewable sources in order to reduce greenhouse gas emissions [2]. Among them, the most important biofuels, in terms of production and mature industrial technologies, are bioethanol and biodiesel. In this latter case, it is produced from the transesterification process of vegetable oils or animal fats with short-chain alcohols, mainly methanol, under either base or acid catalysis, using homogeneous or heterogeneous conditions (Figure 1).

Biodiesel is an environmentally friendly fuel with a relatively low greenhouse effect, because of the lower pollutant gases and particulate matter emissions. In addition, biofuels avoid sulfur emissions and the formation of polycyclic aromatic hydrocarbons, and they are biodegradable in comparison to traditional fossil fuels $[3,4]$.

The triglycerides used for the synthesis of biodiesel (Table 1) are traditionally obtained from several oleaginous plants, such as soybean, palm, sunflower or rapeseed. However, these vegetable oils are also used in food industries; therefore, they must not be considered as sustainable raw materials, 
since they could increase speculation, social imbalances, and the over-exploitation of fertile zones. Thus, the search for alternative oils is necessary, which should not interfere with the food chain. In this sense, an alternative feedstock for the synthesis of biodiesel is used as cooking oil, which is a waste without commercial interest.

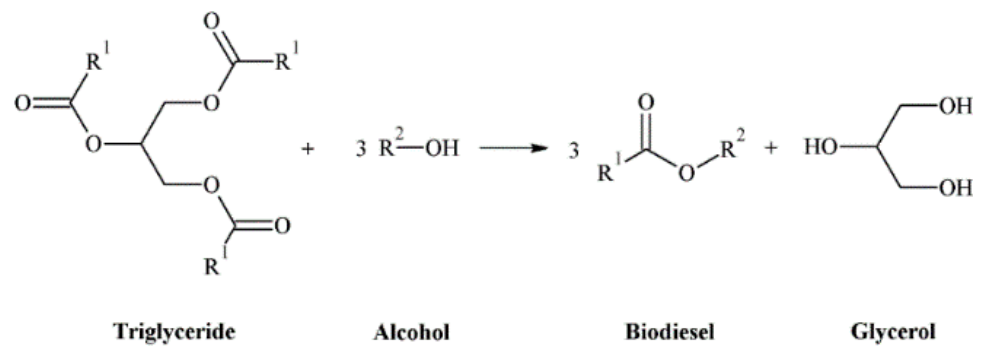

Figure 1. Transesterification reaction for biodiesel synthesis.

Table 1. Current feedstocks for biodiesel production, based on Tan et al. [5].

\begin{tabular}{|c|c|c|}
\hline Feedstock & Types & Remarks \\
\hline First generation & $\begin{array}{ll}- & \text { Palm oil } \\
\text { - } & \text { Rapeseed } \\
\text { - } & \text { Soybean oil } \\
\text { - } & \text { Sunflower oil } \\
\text { - } & \text { Peanut oil }\end{array}$ & $\begin{array}{ll}\text { - } & \text { Food feedstock } \\
\text { - } & \text { Competition with the edible oil market } \\
\text { - } & \text { Impact on food markets and security } \\
\text { - } & \text { Large portions of land are required }\end{array}$ \\
\hline Second generation & $\begin{array}{ll}\text { - } & \text { Jatropha oil } \\
\text { - } & \text { Sea mango } \\
\text { - } & \text { Tobacco seed oil } \\
\text { - } & \text { Tallow } \\
\text { - } & \text { Frying oil }\end{array}$ & $\begin{array}{ll}\text { - } & \text { Low competition with food } \\
\text { - } & \text { Environmentally friendly } \\
\text { - } & \text { Poor performance in cold temperature } \\
\text { - } & \text { Animal fats (biosafety problems) } \\
\text { - } & \text { Valorization of residue }\end{array}$ \\
\hline
\end{tabular}

The transesterification of triglycerides with short-chain alcohols generates biodiesel and glycerol as byproducts (Figure 1), in such a way that about a $10 \mathrm{wt} . \%$ of glycerol, with respect to biodiesel, is produced [6]. In recent years, the worldwide production of biodiesel is growing progressively (Figure 2) [7], and glycerol production has also risen consequently, so this in-stock glycerol should have a commercial outlet to improve the sustainability of biodiesel production.

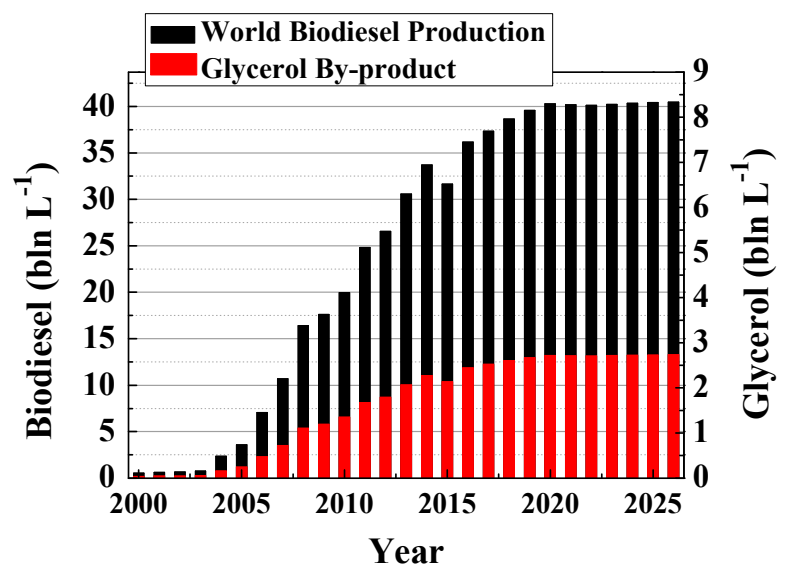

Figure 2. World production of biodiesel and glycerol (predictions of Organisation for Economic Co-Operation and Development/Food and Agriculture Organization of the United Nations (OECD-FAO)) [7]. 
Thus, glycerol can be transformed into value-added products. In this context, the catalytic dehydration of glycerol can yield acrolein, which is a versatile intermediate that is largely employed in the chemical industry. The presence of acid catalysts is needed to provide a suitable control of the reaction for attaining a significant acrolein yield. However, it has been demonstrated that the catalytic activity depends on the textural properties, mainly the pore size, which directly affects the deactivation processes [8-10].

The present review is included within a special issue titled "Mesoporous Silica Catalysts", and this will be focused on the use of catalysts in which the mesoporous silica plays an important role, as support of the active phase or as catalyst itself, in glycerol valorization via its transformation to acrolein.

\section{Glycerol Valorization}

Glycerol is an organic molecule with three hydroxyl groups, which make glycerol very soluble in polar solvents, such as water and alcohols. Moreover, the hydroxyl groups form an extensive network of hydrogen bonds, as their boiling temperature is high in relation to their molecular size. Moreover, its presence provides glycerol molecules with a high versatility and physicochemical properties, allowing direct applications for facilitating the synthesis of high value-added chemicals.

Nowadays, glycerol finds more than 1500 applications across several industries, including food, pharmaceutical, personal care, antifreeze, and vibration dampening, among others [8]. In fact, the United States Department of Energy has considered glycerol to be one of the major building block chemicals [11]. Despite its high potential, the current situation is different, since the crude glycerol obtained from triglycerides transesterification has a low quality, which is one of the reasons for the marginal price of this byproduct. For this reason, it is generally burned, thus wasting this organic raw material with a high potential for obtaining a large spectrum of valuable chemicals.

In this sense, the high glycerol reactivity allows its oxidation, partial or total hydrogenation, dehydration, and esterification or etherification, among other chemical transformations (Figure 3). In addition, glycerol can incorporate other heteroatoms, such as chorine by chlorination, or nitrogen by ammoxidation [12-14]. Among all this plethora of valorization routes, the present review will be focused on dehydration reactions.

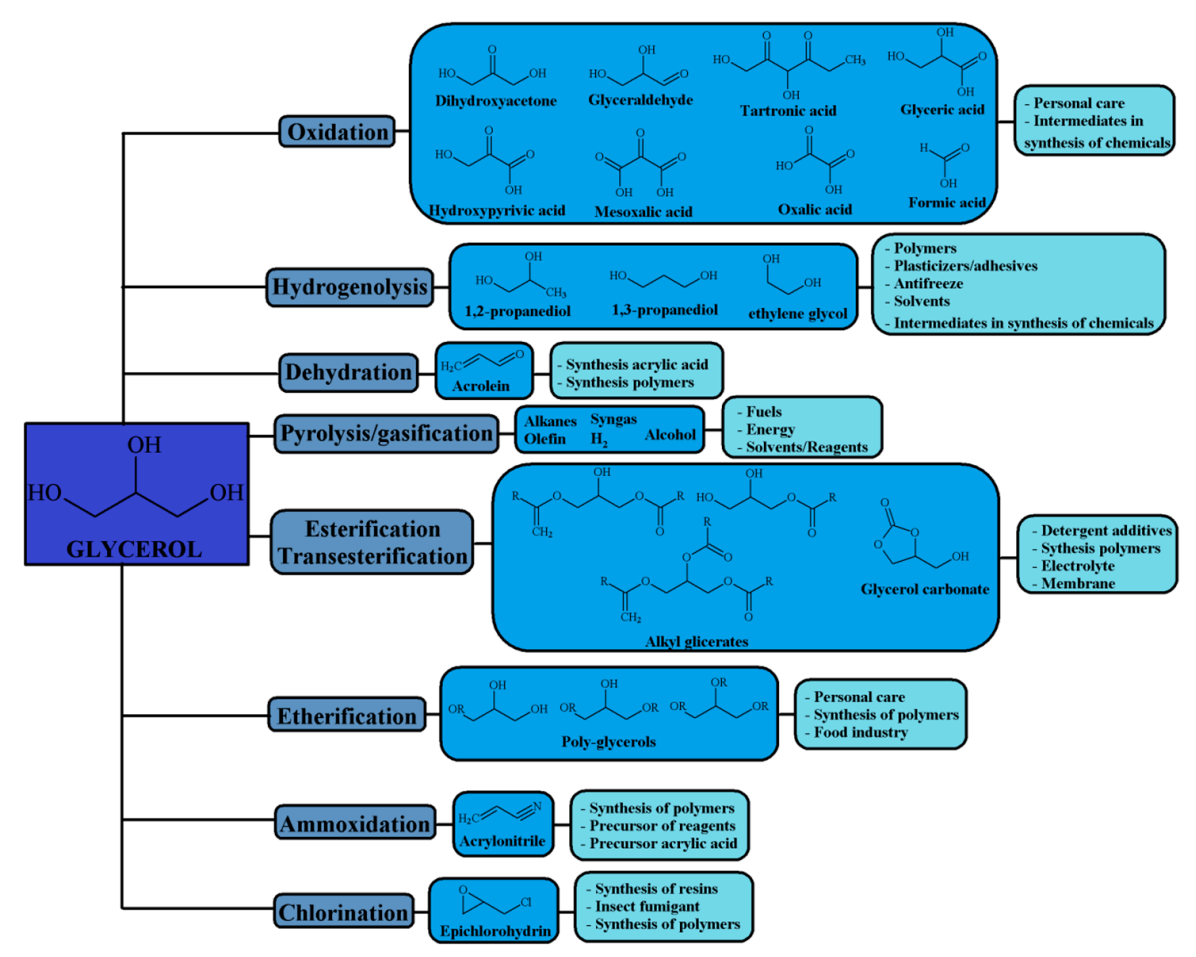

Figure 3. Valorization of glycerol and applications of some value-added products. 


\section{Glycerol Dehydration}

One of the most interesting reactions for glycerol valorization is its dehydration to yield acrolein. This commodity is an important intermediate for the synthesis of methionine, methylpyridines, acrylic acid and esters, detergents, polymers, and super-adsorbents, and it can also be employed as biocide [8,14].

The glycerol dehydration to acrolein has been studied in both gas and liquid phases, although several authors have established that the gas phase is a more sustainable process, due to the operational and environmental issues of liquid phase reactions $[15,16]$. The glycerol dehydration requires acidic conditions, since the protonation of glycerol causes a decrease of the activation energy barrier from about $60 \mathrm{KJ} \mathrm{mol}^{-1}$ to $20 \mathrm{KJ} \mathrm{mol}^{-1}$ [17]. In this context, a relationship has been established between the strength of acid sites, according to the Hammett acidity, and the catalytic activity [18-20]. Thus, catalysts with the highest selectivity toward acrolein were those whose Hammett acidity was in the range $-3<\mathrm{Ho}<-8.2$. Several solid acid catalysts, such as metal sulfates $[18,21,22]$ and phosphates [23-25], metal oxides $\left(\mathrm{Al}_{2} \mathrm{O}_{3}, \mathrm{ZrO}_{2}, \mathrm{TiO}_{2}, \mathrm{WO}_{3}, \mathrm{Nb}_{2} \mathrm{O}_{5}, \mathrm{Ta}_{2} \mathrm{O}_{5}\right)$, zeolites [18,26-36], and heteropolyacids [18,37-40], have shown to be active in glycerol dehydration, with a high selectivity to acrolein. Among these catalysts, metal sulfates and phosphates or heteropolyacids exhibit mainly Brönsted acidity, while others such as $\mathrm{Al}_{2} \mathrm{O}_{3}$ or $\mathrm{ZrO}_{2}$ can be considered Lewis acid catalysts. Nevertheless, the most common is the coexistence of both Brönsted and Lewis acid sites, although it is not still clear which type of acidity is the most beneficial for glycerol dehydration.

Alhanash et al. [39] established that Brönsted acid sites favor the protonation of the secondary hydroxyl group of glycerol, which is easily dehydrated to 1,3-dihydroxypropenal and then, after a keto-enol tautomerization, it is converted to 3-hydroxypropanal, whose subsequent dehydration leads to acrolein (Figure 4).

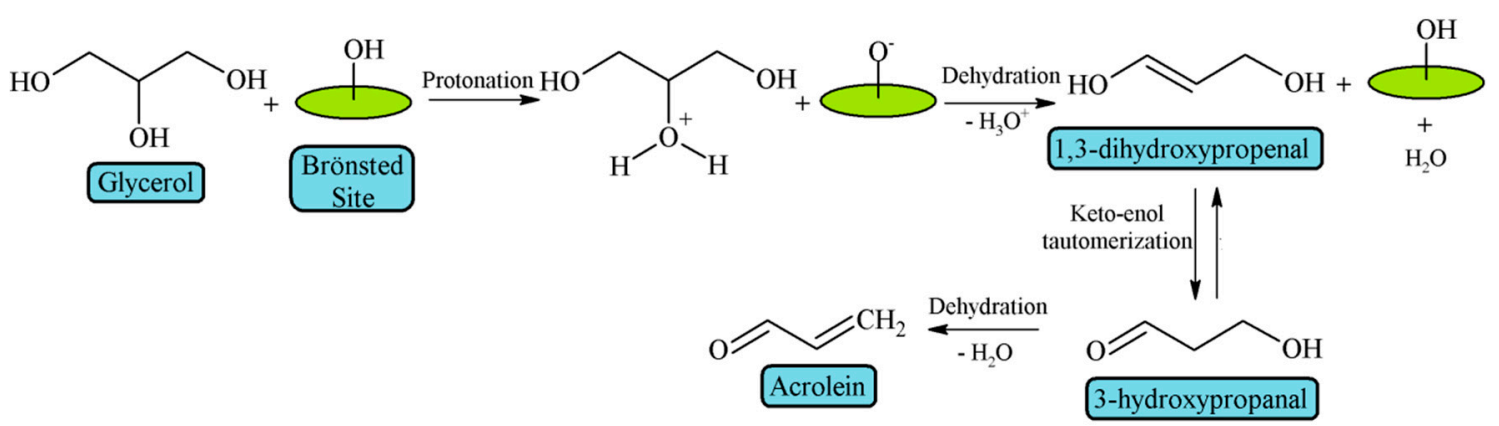

Figure 4. Mechanism of glycerol dehydration on Brönsted acid sites (adapted from Alhanash et al. [39]).

On the other hand, Lewis acid sites preferentially activate the terminal hydroxyl groups due to the steric hindrance [39] (Figure 5). The interaction between a terminal $\mathrm{OH}$ group and a Lewis acid site favors the $\mathrm{H}$ transfer from the secondary $\mathrm{C}$ atom to the bridging $\mathrm{O}$ atom of the metal oxide, giving rise to 2,3-dihydroxypropene, which tautomerizes to acetol (hydroxyacetone), and the Lewis acid site is regenerated by thermal dehydration.

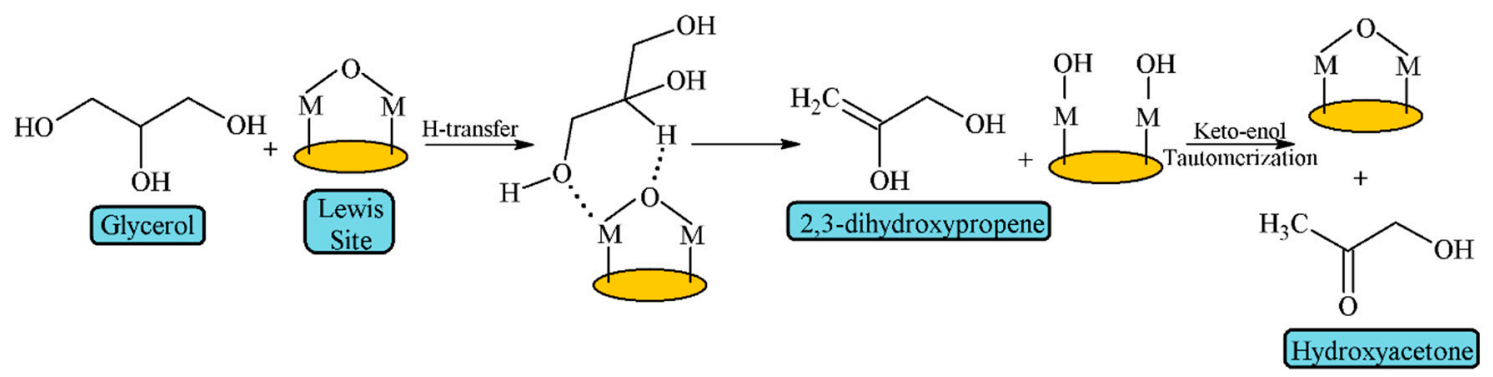

Figure 5. Mechanism of glycerol dehydration on Lewis acid sites (adapted from Alhanash et al. [39]). 
It can be observed that Lewis acid sites are transformed during the formation of 2,3dihydroxypropene into pseudo-Brönsted acid sites, which can also lead to acrolein, or be regenerated to act as Lewis acid, favoring the formation of acetol [8].

On the other hand, Laino et al., from Density Functional Theory (DFT) studies, have proposed an alternative mechanism for glycerol dehydration to acrolein [41] (Figure 6). They suggest that the reaction takes place on Brönsted acid sites, generating an epoxide (glycidol) prior to the formation of 1,3-dihydroxypropenal. Then, this aldehyde is dehydrated to form acrolein, or an intramolecular hydrogen-transfer reaction can occur, leading to formaldehyde and vinyl alcohol.

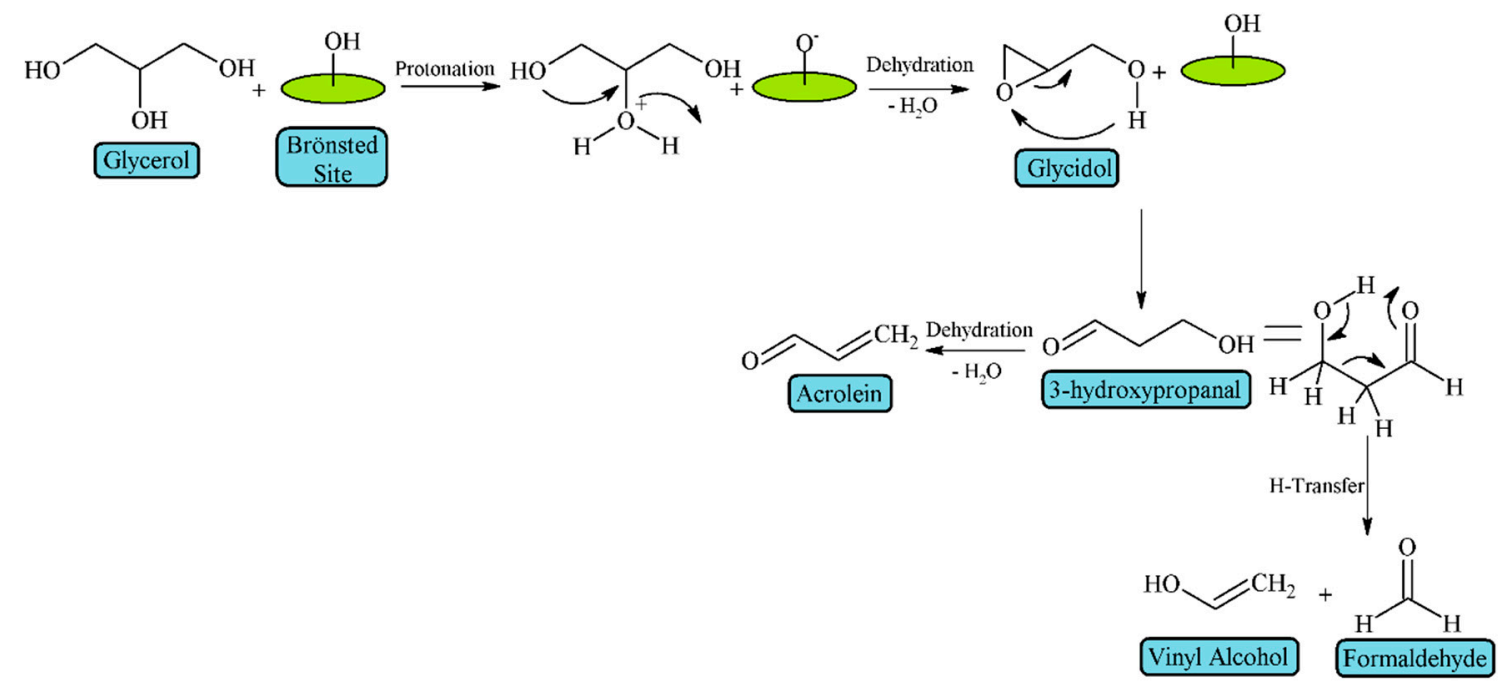

Figure 6. Alternative mechanism of glycerol dehydration on Brönsted acid sites (adapted from Laino et al. [41]).

However, it has been reported that other factors influence the catalytic performance besides the catalyst acidity, such as its textural properties. Thus, Tsukuda et al. [9] evaluated different supported heteropolyacids as catalysts for glycerol dehydration to acrolein, demonstrating that the catalytic activity depended on the type of heteropolyacid and on the size of mesopores of the silica support. They reported that silicotungstic acid supported on silica with mesopores of $10 \mathrm{~nm}$ exhibited a stable catalytic activity, obtaining a $C_{\text {gly }}$ (glycerol conversion) $=100 \%$ and $Y_{\text {acrol }}$ (Acrolein Yield) $=86 \%$ ) in such a way that the size of the mesopores affected the catalytic activity, since small mesopores of $3 \mathrm{~nm}$ induced deactivation $\left(\mathrm{C}_{\mathrm{gly}}=55 \%\right.$ and $\mathrm{Y}_{\mathrm{acrol}}=36 \%$ ). Likewise, Pathak et al. [10] studied Zeolite Socony Mobil-5 (ZSM-5) zeolites with different pore sizes $(0.54 \mathrm{~nm}, 0.74 \mathrm{~nm}, 3.15 \mathrm{~nm}$, and $11.2 \mathrm{~nm})$ and detected that the acrolein selectivity enhanced with the pore size, although selectivity toward other byproducts, such as formaldehyde, acetaldehyde, or hydroxyacetone, also increased. Therefore, the presence of mesopores seems to be directly related to the catalytic activity.

\section{Mesoporous Silica-Based Catalysts Used in the Glycerol Dehydration}

In this section, the most relevant silica-based catalytic systems studied for glycerol dehydration will be reviewed, in particular those employing a mesoporous silica as support or catalyst.

\subsection{Mesoporous Silica}

Since the Mobil company (Irving, TX, Estados Unidos) discovered the M41S family of mesoporous materials in 1992, much attention has been paid to mesoporous silica due to its use as catalyst in the oil refining and petrochemical industry or its use as adsorbent in separation processes. The synthesis of these mesoporous solids is based on the use of cationic surfactants as structure-directing agents (SDA) for the formation of the hybrid organo-inorganic precursor, which after subsequent calcination, or 
surfactant extraction, gives rise to a mesoporous framework. The formation of micellar structures helps build up the siliceous framework by polymerization of the silica precursors. This methodology allows the synthesis of mesoporous solids with a narrow pore size distribution, ranging between 2-6.5 $\mathrm{nm}$ [42]. Later, Stucky et al. at the University of Santa Barbara synthesized a new ordered mesoporous silica, using triblock copolymers as SDA, originating materials with pore diameters between 5-30 nm [43]. Their high specific surface area together with a narrow pore size distribution favored the dispersion of active phases and the diffusion of molecules. The use of these mesoporous materials in glycerol dehydration is compiled in Table 2.

On the other hand, the presence of silanol groups $(-\mathrm{Si}-\mathrm{OH})$ on the silica walls allows the surface functionalization of the mesoporous silica by grafting. Thus, several authors functionalized the SBA-15 mesochannels by the grafting of mercaptopropyl trimethoxysilane. The - $\mathrm{SH}$ groups were then oxidized with $\mathrm{H}_{2} \mathrm{O}_{2}$ to generate sulfonic groups $\left(\mathrm{SO}_{3} \mathrm{H}\right)$ (Figure 7). These catalysts were active in the dehydration of glycerol due to the presence of Brönsted-type acidity on the surface of the mesoporous silica $[44,45]$.

Table 2. Catalytic activity of catalysts based on mesoporous silica in glycerol dehydration.

\begin{tabular}{|c|c|c|c|c|c|c|}
\hline Active Phase & $\mathrm{T}\left({ }^{\circ} \mathrm{C}\right)$ & TOS (h) & $\mathrm{C}_{\text {gly }}(\%)$ & $\mathrm{Y}_{\mathrm{acrol}}(\%)$ & $\mathrm{Mmol}_{\text {acrol }} \mathrm{h}^{-1} \mathrm{~g}_{\mathrm{cat}}{ }^{-1}$ & Ref. \\
\hline SBA-15- $\mathrm{SO}_{3} \mathrm{H}$ & 300 & 3 & 100 & 93 & 10.5 & [44] \\
\hline SBA-15- $\mathrm{SO}_{3} \mathrm{H}$ & 300 & 6 & 45 & 35 & 13.9 & [45] \\
\hline SBA-15- $-\mathrm{PO}_{3} \mathrm{H}$ & 320 & 2 & 97 & 81 & 3.71 & [46] \\
\hline Meso $\mathrm{SiO}_{2}-\mathrm{ZrO}_{2} / \mathrm{SO}_{4}{ }^{2-}$ & 250 & 2 & 99 & 81 & 10.9 & [47] \\
\hline $\mathrm{H}_{3} \mathrm{PW}_{12} \mathrm{O}_{40} / \mathrm{MCM}-41$ & 320 & 2 & 85 & 68 & 3.72 & [48] \\
\hline $\mathrm{H}_{3} \mathrm{PW}_{12} \mathrm{O}_{40} / \mathrm{MCM}-41$ & 320 & 5 & 87 & 44 & 3.59 & \\
\hline $\mathrm{H}_{6} \mathrm{P}_{2} \mathrm{~W}_{18} \mathrm{O}_{62} / \mathrm{MCM}-41$ & 320 & 5 & 82 & 51 & 4.20 & [49] \\
\hline $\mathrm{Cs}_{2.5} \mathrm{H}_{0.5} \mathrm{PW}_{12} \mathrm{O}_{40} / \mathrm{MCM}-41$ & 300 & 2 & 100 & 86 & 8.47 & {$[50]$} \\
\hline $\mathrm{Cs}_{2.5} \mathrm{H}_{0.5} \mathrm{PW}_{12} \mathrm{O}_{40} / \mathrm{MCM}-41$ & 300 & 30 & 100 & 88 & 24.08 & [51] \\
\hline MCM41-Zr & 320 & 5 & 74 & 19 & 0.87 & \\
\hline Pd-HPW / Zr-MCM-41 & 320 & 5 & 94 & 80 & 3.64 & [52] \\
\hline Pt-HPW / Zr-MCM-41 & 320 & 5 & 83 & 62 & 2.82 & \\
\hline MCM41-Zr & 300 & 5 & 66 & 18 & 5.31 & \\
\hline Pt-HPW / Zr-MCM-41 & 350 & 5 & 82 & 70 & 20.31 & [53] \\
\hline $\mathrm{H}_{4} \mathrm{PMo}_{11} \mathrm{VO}_{40} / \mathrm{SBA}-15$ & 225 & 4 & 100 & 74 & 1.69 & [54] \\
\hline MCM41-Zr & 315 & 5 & 97 & 38 & 5.28 & [55] \\
\hline MCM41-Zr & 250 & $0-5$ & 96 & 71 & 4.86 & [56] \\
\hline $\mathrm{V}_{2} \mathrm{O}_{5} / \mathrm{MCM} 41-\mathrm{Zr}$ & 325 & 2 & 90 & 25 & 4.41 & \\
\hline $\mathrm{V}_{2} \mathrm{O}_{5}-\mathrm{P} / \mathrm{MCM} 41-\mathrm{Zr}$ & 325 & 2 & 90 & 41 & 6.71 & {$[5$} \\
\hline $\mathrm{Nb}_{2} \mathrm{O}_{5} / \mathrm{MCM}-41-\mathrm{Zr}$ & 325 & 2 & 77 & 45 & 7.43 & {$[58]$} \\
\hline $\mathrm{WO}_{3} / \mathrm{MCM}-41-\mathrm{Zr}$ & 325 & 2 & 97 & 41 & 6.71 & \\
\hline $\mathrm{WO}_{3}-\mathrm{P} / \mathrm{MCM}-41-\mathrm{Zr}$ & 325 & 2 & 78 & 51 & 8.36 & [59] \\
\hline $\mathrm{Nb}_{2} \mathrm{O}_{5}-\mathrm{P} / \mathrm{MCM}-41-\mathrm{Zr}$ & 325 & 2 & 100 & 56 & 9.18 & {$[60]$} \\
\hline Al-SBA-15 & 325 & 2 & 94 & 35 & 5.74 & [61] \\
\hline
\end{tabular}

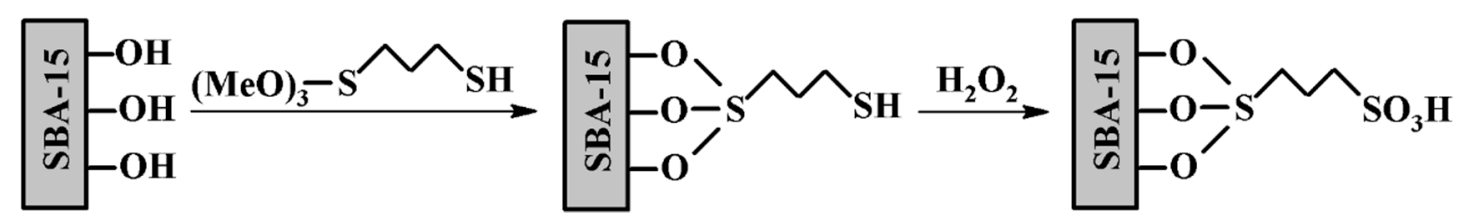

Figure 7. Functionalization of silica with sulfonic groups.

Lourenço et al. found that sulfonic acid groups incorporated to SBA-15 by the addition of 3-mercaptopropyltrimethoxysilane, which achieved a high acrolein yield $(93 \%)$ and minimized the catalyst deactivation (Table 2). In addition, the large pore size of open channels of the SBA-15 silica favored the mass transfer and prevented deactivation [44]. These authors affirmed that both the pore 
size and density of acid sites played an important role in the deactivation rate and selectivity pattern, since a larger pore size significantly improved the catalytic activity, whereas a high density of acid sites could reduce acrolein production. However, Dalla Costa et al. observed a progressive deactivation under more severe reaction conditions (Table 2) [45]. They found that higher temperatures led to rapid deactivation due to a combined effect associated with coke deposition and the decomposition of sulfonic acid groups. Thus, temperatures above $300^{\circ} \mathrm{C}$ provoked an irreversible deactivation. In both cases, the sulfonic acid groups were highly selective toward acrolein, with hydroxyacetone being a minor product and the density of sulfonic groups directly related to the catalytic activity.

Another strategy to generate Brönsted acid sites on the surface of mesoporous MCM-41 silica was by impregnation with phosphoric acid and subsequent calcination [46]. This catalyst followed the same trend as that observed for the mesoporous silica functionalized with sulfonic acid groups, since the main product was acrolein (Table 2) with a negligible amount of hydroxyacetone. This catalyst maintained the glycerol conversion ( $97 \%$ ) during $10 \mathrm{~h}$, but deactivation by coke deposition was detected for a longer reaction time, which was more pronounced than that observed for SBA-15 silica due to the narrower pore size of MCM-41, which favors a faster pore blockage. However, the $\mathrm{H}_{3} \mathrm{PO}_{4}$-modified MCM-41 catalyst recovered its activity after regeneration by a simple oxidative treatment in air.

Kobayashi et al. studied a mesoporous sulfated zirconia/silica catalyst with $20 \mathrm{wt} . \% \mathrm{SO}_{4}{ }^{2-}$ in the catalyst, which was incorporated by using $\left(\mathrm{NH}_{4}\right)_{2} \mathrm{SO}_{4}$ solutions [47]. They observed that sulfate groups provided Brönsted acid sites, although the most active and stable catalyst was that with a lower proportion of Brönsted acid sites, since its higher surface area minimized the formation of carbonaceous deposits. They proposed the existence of weak acid sites due to the dilution of zirconium species into silica, whereas the large pore size is suitable for a faster diffusion of glycerol, giving rise to better catalytic performance. The catalyst deactivation took place without the loss of sulfur, being ascribed to the covering of acid sites by coke.

The use of mesoporous silica also allows hosting and dispersing bulky polyoxocations, such as heteropolyacids, which enhance the acidity strength, especially of Brönsted acid sites. Thus, Ding et al. incorporated different loadings of $\mathrm{H}_{3} \mathrm{PW}_{12} \mathrm{O}_{40}$ into MCM-41 by impregnation, maintaining within the resulting solids a high specific surface area, determined by the Brunauer, Emmett and Teller (BET) equation, $\mathrm{S}_{\text {BET }}\left(415-624 \mathrm{~m}^{2} \mathrm{~g}^{-1}\right)$ and pore size values $(2.5-2.7 \mathrm{~nm})$. The highest catalytic activity $\left(\mathrm{C}_{\text {gly }}=85 \%\right.$ and $\left.\mathrm{Y}_{\text {acrol }}=65 \%\right)$ (Table 2$)$ was found for the catalyst with a $40 \mathrm{wt} . \%$ of $\mathrm{H}_{3} \mathrm{PW}_{12} \mathrm{O}_{40}$ [48]. Alike, Ma et al. compared two phosphotungstic acids $\left(\mathrm{H}_{6} \mathrm{P}_{2} \mathrm{~W}_{18} \mathrm{O}_{62}\right.$ and $\left.\mathrm{H}_{3} \mathrm{PW}_{12} \mathrm{O}_{40}\right)$ supported on MCM-41 by using the wet impregnation method [49]. They established from pyridine adsorption coupled to Fourier transform infrared (FT-IR) spectroscopy that a $\mathrm{H}_{3} \mathrm{PW}_{12} \mathrm{O}_{40} / \mathrm{MCM}-41$ catalyst showed a higher total acidity, mainly of Lewis type, while $\mathrm{H}_{6} \mathrm{P}_{2} \mathrm{~W}_{18} \mathrm{O}_{62} / \mathrm{MCM}-41$ displayed the highest Brönsted:Lewis acid sites ratio. These data could be correlated with the catalytic behavior, since $\mathrm{H}_{6} \mathrm{P}_{2} \mathrm{~W}_{18} \mathrm{O}_{62} / \mathrm{MCM}-41$, with a higher proportion of Brönsted acid centers, was more selective toward acrolein (Table 2). On the other hand, the presence of a higher fraction of Lewis acid sites in $\mathrm{H}_{3} \mathrm{PW}_{12} \mathrm{O}_{40} / \mathrm{MCM}-41$ catalyst caused a decrease in the acrolein selectivity, with a concomitant increase in hydroxyacetone. They also confirmed that catalyst deactivation was caused by both the leaching of HPW species and coke deposition.

One of the main drawbacks related to the use of heteropolyacids supported on mesoporous silica is related to their deactivation. Due to the high catalytic activity of this phase, leading to high acrolein yields, carbonaceous deposits are easily generated that block mesochannels, which gives rise to a faster deactivation associated with diffusional limitations. In this regard, several authors have proposed that the incorporation of $\mathrm{Cs}^{+}$species into heteropolyacids supported on mesoporous silica can minimize the deactivation by coke deposition, since $\mathrm{Cs}^{+}$partially neutralizes the strongest acid sites of heteropolyacids (Table 2) [50,51]. Other cations, such as $\mathrm{Na}^{+}$or $\mathrm{K}^{+}$, were also proposed in order to reduce the formation of carbonaceous deposits; however, these cations drastically decrease the number of strong acid centers, which led to a lower catalytic activity and yield toward acrolein [51]. 
The deactivation also minimized incorporating $\mathrm{O}_{2}$ in the gas carrier, although the oxygen concentration had to be limited, since carbonaceous deposits could burn [50].

Other authors pointed out that the doping of heteropolyacids supported on mesoporous silica with noble metals, such as $\mathrm{Pd}$ or $\mathrm{Pt}$, could reduce the coke, thus ameliorating the catalytic performance (Table 2) $[52,53]$. Trakarnpurk confirmed that the presence of platinum improved the long-term stability of a ZrMCM-41 impregnated with $2 \% \mathrm{Pt}$ and $35 \%$ phosphotungstic acid catalyst [53]. The Pt-free catalyst exhibited an abrupt decrease in conversion (until $60 \%$ after $20 \mathrm{~h}$ of time-on-stream) due to coke deposition. In the same way, Ma et al. [52] demonstrated that a $\mathrm{Pd}-\mathrm{H}_{3} \mathrm{PW}_{12} \mathrm{O}_{40} / \mathrm{Zr}-\mathrm{MCM}-41$ catalyst, prepared by impregnation, significantly enhanced the acrolein selectivity, with lower coke deposition and improved stability, with the support mesostructure remaining almost unchanged.

On the other hand, Viswanadham et al. established that the incorporation of vanadium species in the heteropolyacid structure also minimized the coke deposition, due to the redox properties of vanadium species retarding the deactivation [54]. These authors also observed a faster deactivation for the heteropolyacid supported in porous materials with a narrower pore diameter (Y-zeolite), while the use of large pore supports, such as SBA-15, maintained the catalytic activity for longer reaction times, because larger channels can avoid the pore blockage. However, the pore size distribution must be tuned to ensure an appropriate interaction between glycerol and the active centers.

The incorporation of heteroatoms, such as zirconium (IV) or aluminum (III), into a mesoporous silica is a classical methodological approach to generate acid sites for glycerol dehydration. Thus, the substitution of an $\mathrm{Si}$ (IV) atom by a heteroatom increases the acid strength of $\mathrm{Si}-\mathrm{OH}$ groups, whereas the formation of $\mathrm{M}-\mathrm{OH}-\mathrm{Si}$ linkages, similarly to $\mathrm{Si}-\mathrm{OH}-\mathrm{Al}$ groups in zeolites, creates new Brönsted acid sites $[55,62,63]$. In this process, Lewis acid sites can be also formed, which are associated with deficiently coordinated heteroatoms. However, these Lewis acid centers can be transformed into pseudo-Brönsted sites by the water present in the reaction medium, as previously reported [8]. García-Sancho et al. synthesized a zirconium-doped mesoporous MCM-41 silica, incorporating $\mathrm{Zr}$ species into the siliceous framework, with different $\mathrm{Si} / \mathrm{Zr}$ molar ratios (4-12), obtaining a maximum glycerol conversion of $97 \%$ with an acrolein yield of $39 \%$ after $2 \mathrm{~h}$ of time-on-stream at $325{ }^{\circ} \mathrm{C}$ for a $\mathrm{Si} / \mathrm{Zr}$ molar ratio of five (Table 2) [55]. They also detected a high proportion of acetaldehyde, which can be formed by the retro-aldol fragmentation of 3-hydroxypropanal at reaction temperatures above $30{ }^{\circ} \mathrm{C}$ [52]. However, other authors established that acetaldehyde could result from the decomposition of hydroxyacetone [64]. Unfortunately, Zr-MCM-41 catalysts showed a rapid deactivation. Moreover, heteroatom-doped mesoporous silica has been used as a support of heteropolyacids. This work aims to weaken the strength of the Brönsted acid sites being associated with heteropolyacids by their interaction with the support. Consequently, the formation of carbonaceous deposits was reduced, leading to more stable catalysts $[52,56]$. It was also observed that the presence of zirconium into the siliceous framework favored the catalyst regeneration in comparison to the catalyst without zirconium [65].

Different metal oxides, such as $\mathrm{V}_{2} \mathrm{O}_{5}$ [57], $\mathrm{Nb}_{2} \mathrm{O}_{5}$ [58], and $\mathrm{WO}_{3}$ [59], have been incorporated into a mesoporous silica doped with zirconium by incipient wetness impregnation using vanadyl acetylacetonate, niobium oxalate, and ammonium metatungstate hydrate as precursor salts, respectively, causing an increase in both Lewis and Brönsted acidity, due to the interaction of zirconium species with metal oxides. Brönsted and Lewis acid sites, which are transformed into pseudo-Brönsted acid sites, favored acrolein formation and reduced their deactivation by coke. In all of the cases, the thermal decomposition of acrolein led to acetaldehyde as byproduct. It can be observed in Table 2 that supported $\mathrm{Nb}_{2} \mathrm{O}_{5}$ species were more selective to acrolein than $\mathrm{V}_{2} \mathrm{O}_{5}$ and $\mathrm{WO}_{3}$. Later, phosphorus species were incorporated to these metal oxides, obtaining an amorphous pseudo-heteropolyacid after calcination $[57,59,60]$. The incorporation of high phosphorus contents by using phosphoric acid solutions caused a pore blockage, so the catalytic processes in these cases could take place mainly on the external surface. In spite of the decay of the specific surface area, the density of acid sites increased, as well as the proportion of Brönsted acid sites, leading to a higher acrolein yield and a decrease in 
carbon deposits. Therefore, these catalysts were more stable along the time-on-stream, even if only active sites located on the external surface were involved in the catalytic process.

On the other hand, Cecilia et al. employed a low-cost SBA-15 synthesized from sodium silicate, and carried out a partial extraction of the silicon species from the siliceous framework using basic conditions [61]. Later, aluminum species were incorporated into the siliceous framework by mixing different volumes of a $1.2 \mathrm{M} \mathrm{AlCl}_{3} \cdot 6 \mathrm{H}_{2} \mathrm{O}$ aqueous solution with $25 \mathrm{~mL}$ of tetramethylammonium hydroxide aqueous solution. The existence of two kinds of aluminum sites was inferred from ${ }^{27} \mathrm{Al}-\mathrm{NMR}$ spectroscopy: tetrahedral Al located inside the silica walls and extra-framework octahedral Al species. Pyridine adsorption studies indicated that the tetrahedral aluminum generated Brönsted acid sites, while the presence of octahedral aluminum, whose amount rose with the Al loading, caused an increment of total acidity and the amount of Lewis acid sites, but the concentration of Brönsted acid sites decreased. Therefore, a higher proportion of aluminum did not produce an increase in tetrahedral aluminum, since firstly, the aluminum was introduced into the framework defects, and the excess remained on the external surface of SBA-15 as octahedral aluminum, which displayed a lower catalytic activity in glycerol dehydration to acrolein. Although the acrolein yield was lower than that obtained for other catalysts (Table 2) and the active sites suffered deactivation by coke deposition, this Al-SBA-15 catalyst could be interesting, since it is a simple and inexpensive catalyst and it could be reused, at least during three catalytic cycles after thermal regeneration.

\subsection{Zeolites}

Zeolites have demonstrated to be highly active in glycerol dehydration to acrolein, due to the existence of strong Brönsted acid centers in the microporous structure. The catalytic data reveal that the $\mathrm{SiO}_{2} / \mathrm{Al}_{2} \mathrm{O}_{3}$ ratio is not the only factor influencing glycerol conversion and the selectivity pattern, but there must be other factors involved in the catalytic performance, such as the type of zeolitic framework or the pore dimensions and topology $[32,34,66]$. In general, the catalytic activity was directly related to the amount and strength of Brönsted acid sites, although the dimensions of cavities played a key role in determining the resistance to deactivation [34,67-69]. As the current review is only focused on mesoporous silica catalysts, microporous zeolites used in glycerol dehydration will not be dealt with.

Kim et al. [34] compared the catalytic performance of $\mathrm{H}-\beta, \mathrm{H}$-ferrierite, H-ZSM-5, H-Y, and $\mathrm{H}$-mordenite with different $\mathrm{SiO}_{2} / \mathrm{Al}_{2} \mathrm{O}_{3}$ molar ratios $\left(\mathrm{SiO}_{2} / \mathrm{Al}_{2} \mathrm{O}_{3}=5.1-350\right)$. The glycerol conversion was strongly dependent on their external surface area. However, most of the pores, mainly micropores, were filled with carbonaceous species at the initial stage of this reaction, provoking the catalyst deactivation. Carriço et al. employed a MCM-22 with different $\mathrm{SiO}_{2} / \mathrm{Al}_{2} \mathrm{O}_{3}$ molar ratios (30-80) prepared by using silica and aluminum nitrate as solid acid catalyst [66], and concluded that its crystallinity, as well as its textural properties, worsen for higher $\mathrm{SiO}_{2} / \mathrm{Al}_{2} \mathrm{O}_{3}$ molar ratios. Although MCM-22 catalysts were essentially microporous, the presence of secondary mesopores was detected. However, they found that an increase in the $\mathrm{SiO}_{2} / \mathrm{Al}_{2} \mathrm{O}_{3}$ molar ratio was accompanied by a reduction of the external surface area and a decrease of the mesoporous volume. The catalytic data showed that the catalyst with the highest acidity was that with the lowest $\mathrm{SiO}_{2} / \mathrm{Al}_{2} \mathrm{O}_{3}$ molar ratio, reaching the best acrolein yield.

Therefore, the coke deposition is directly related to the porous structure. Thus, zeolites with narrower pores are more susceptible to suffer pore blockage, and consequently they are deactivated more quickly. However, zeolites with larger pore volume, or open channels, are more resistant to blockage after short reaction times, since the diffusion is favored. Rodrigues et al. confirmed, by analyzing the carbonaceous deposits by ${ }^{13} \mathrm{C}-\mathrm{NMR}$, the existence of aromatic and polyglycol deposits (Figure 8A-C) $[68,70]$. They concluded that polyaromatic species are formed inside pores on highly active Brönsted acid centers (Figure $8 \mathrm{D}_{1}$ ), in the first hours of reaction, whereas polyglycol deposits took place on the external surface of zeolites, since glycerol molecules were not able to access to the zeolitic cavities (Figure $8 \mathrm{D}_{2}$ ). 


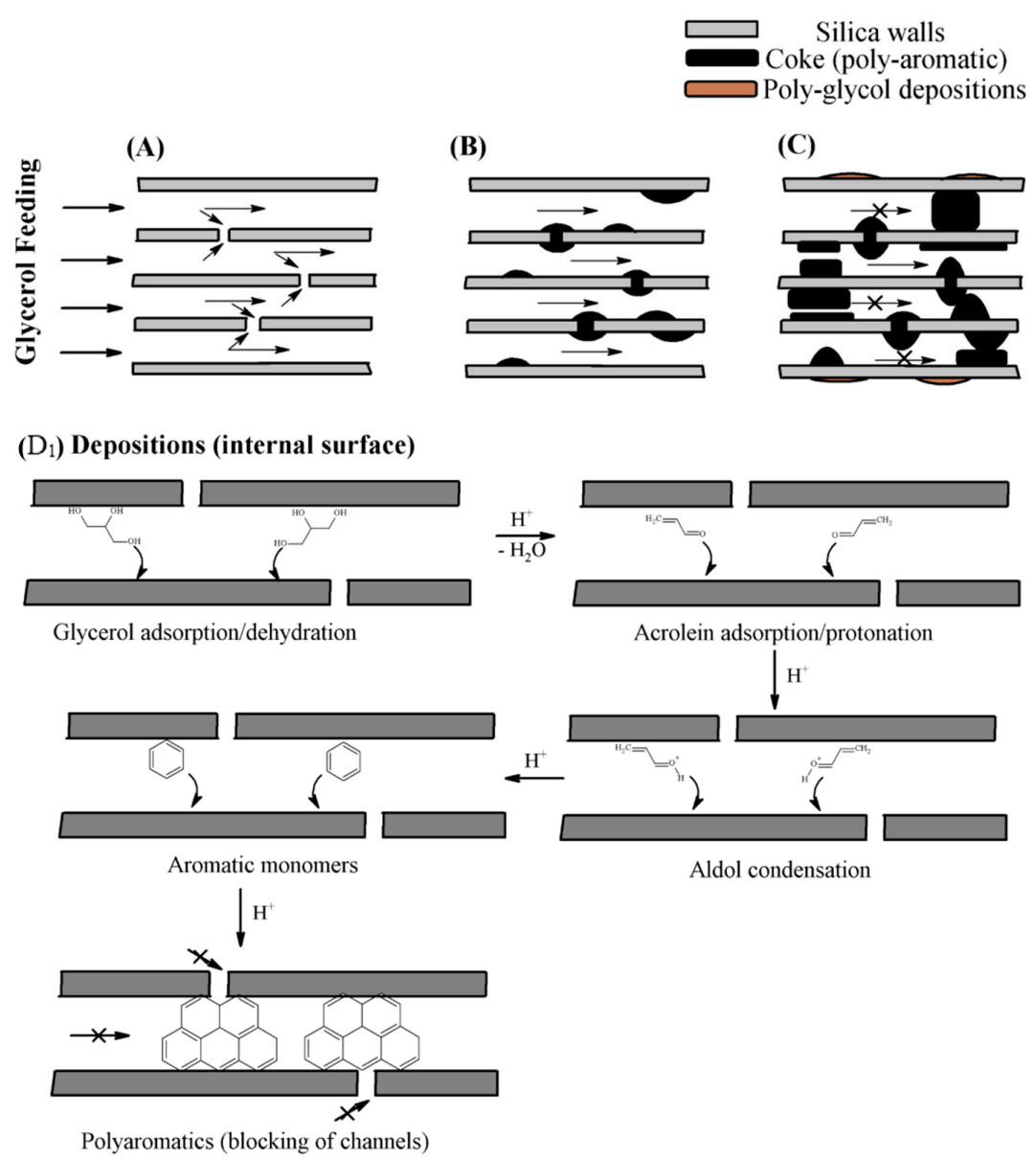

( $\left.D_{2}\right)$ Depositions (external surface)

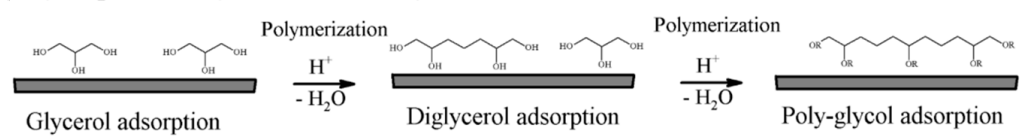

Figure 8. Scheme of the formation of carbonaceous deposits (A-C). Deposits formed on the internal surface $\left(\mathbf{D}_{1}\right)$ and deposits formed on the external surface $\left(\mathbf{D}_{2}\right)$.

In order to obtain more stable catalysts along the time-on-stream, the generation of mesoporosity by partial structural desilication, under basic conditions, has been proposed. Under these alkaline conditions, by using $\mathrm{NaOH}$ solutions, the $\mathrm{SiO}_{2} / \mathrm{Al}_{2} \mathrm{O}_{3}$ molar ratio should decrease, leading to a higher amount of available acid sites [71]. However, the desilication also caused the extraction of aluminum, which generated Lewis acid sites, so the selectivity to hydroxyacetone may increase. The catalyst stability was improved upon desilication due to an increase in coke tolerance. In addition, $\mathrm{NH}_{3}$-thermoprogrammed desorption ( $\mathrm{NH}_{3}$-TPD) studies revealed a decrease of surface acidity strength, so the desilication had an antagonist effect [72]. Nonetheless, other authors pointed out that the Lewis acidity has a cooperative role with neighboring Brönsted centers, improving the catalytic activity [73]. In order to remove the extra-framework alumina associated with Lewis acidity, Lari et al. carried out a subsequent acid treatment to dissolve the aluminum debris, producing an improvement in the selectivity toward acrolein [74].

The coke deactivation can also be slowed down by synthesizing hierarchical zeolites with lower channel lengths. Thus, Zhang et al. evaluated the influence of the mesoporosity and acidity of hierarchical H-ZSM-5 zeolites on the catalytic performance, obtaining a higher coke resistance for the H-ZSM-5 with abundant open inter-crystalline mesopores, maintaining a full glycerol conversion after $14 \mathrm{~h}$ of time-on-stream (TOS) [75]. On the contrary, H-ZSM-5 catalysts with closed intercrystalline pores start 
to deactivate after $6 \mathrm{~h}$ of TOS [75]. Therefore, these results confirmed that an open and interconnected mesoporous architecture leads to a high activity, long lifetime, and improved selectivity, while the worse behavior of closed and small mesopores was attributed to the mass transfer limitations and/or the in-pore condensation of reactant or heavier reaction products. They also emphasized the need to design zeolites with proper hierarchical structure and acidity for maximal catalytic performance.

In the same way, Beerthuis et al. compared a commercial H-ZSM-5 with a hierarchical H-ZSM-5, micro-H-ZSM-5, and nano-H-ZSM-5 [76], being the catalytic results directly related to textural parameters. In this sense, the hierarchical H-ZSM-5 zeolite, with a higher pore volume and lower microporosity, reached the highest glycerol conversion and selectivity to acrolein, while the micro-H-ZSM-5, formed by microsized crystals with small micropores, suffered a faster deactivation by pore blocking. They related the improved stability and coking resistance to the hierarchical porosity formed by micropores, mesopores, and macropores. A similar result was reported by Huang et al., which synthesized a hierarchical H-ZSM-5 by an ultrasound-assisted method, obtaining a catalyst with longer life than the commercial catalyst [77].

Dos Santos et al. prepared ferrierite zeolites in fluoride medium as a mineralizing agent, which resulted in the formation of large crystals [78]. These authors compared the textural properties and catalytic behavior with that of a ferrierite synthesized by the classical method using a hydroxide medium. They found that the ferrierite zeolite synthesized in fluoride medium displayed a lower density of acid sites, which was probably due to the existence of Al-F bonds instead of Al-OH bonds; however, this catalyst was more active and stable than the traditional ferrierite.

Viswanadham et al. generated a high amount of Brönsted acid sites into a Y-zeolite by incorporating 10-40 wt.\% of $\mathrm{H}_{3} \mathrm{PW}_{12} \mathrm{O}_{40}$ using a wetness impregnation method [79]. They attained the highest acrolein yield (79\%) after $3 \mathrm{~h}$ of TOS at $275{ }^{\circ} \mathrm{C}$ for the catalyst with a $20 \mathrm{wt} . \%$ of $\mathrm{H}_{3} \mathrm{PW}_{12} \mathrm{O}_{40}$. However, the use of a higher loading of heteropolyacids did not improve the activity and/or the stability of the catalyst, which was explained by the partial collapse of the zeolite structure, as deduced from textural characterization. Thus, the acrolein selectivity decreased for higher phosphotungstic acid loadings due to the diffusional limitations associated with the smaller pore size.

Again, the incorporation of a low amount of noble metals helped to minimize the coke formation, delaying the catalyst deactivation. These noble metals can be catalytically active, giving rise to other high value-added products. In this sense, Lari et al. synthesized bifunctional catalysts based on noble metals (Ag, Au, Pd, Pt, and Ru) with a 5 wt.\% metal loading supported on a Mordenite Framework Inverted (MFI) type zeolite treated under basic conditions with $\mathrm{NaOH}$ aqueous solutions to increase the dimensions of cavities [74]. They pointed out that the alkaline treatment generates an auxiliary network of intracrystalline mesopores, thus increasing the coking resistance and providing a longer lifetime in glycerol dehydration. The catalytic results revealed that the zeolite catalyzed the dehydration of glycerol to acrolein, while the noble metal acted as hydrogenation sites for acrolein, obtaining the highest allyl alcohol selectivity for the Ag-based catalyst and the highest propanal selectivity for the Pd-based and Pt-based catalysts.

The incorporation of vanadium species in zeolites also exerts a beneficial effect on dehydration reactions due to the redox properties associated with vanadium, slowing the deactivation by coke. Moreover, the use of $\mathrm{O}_{2}$ as co-feed retarded the deactivation process and also favored the oxidation reaction of acrolein to acrylic acid in a process called oxidehydration (Figure 9). Acrylic acid is a valuable compound that is used in the manufacture of plastics, coatings, adhesives, and elastomers, as well as floor polishes and paints.

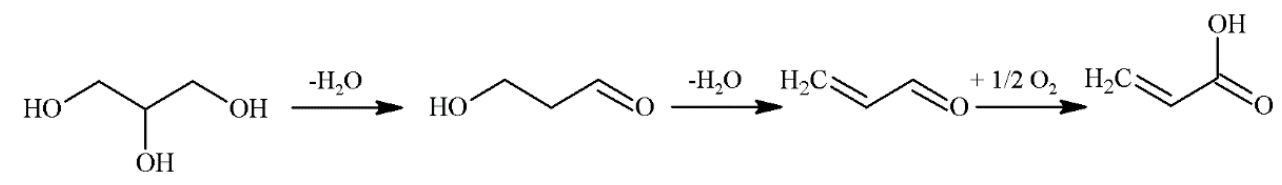

Figure 9. Reaction of glycerol oxidehydration to acrylic acid. 
In a detailed study, several zeolites with different textural properties were impregnated with vanadium (5 wt.\%) by using $\mathrm{NH}_{4} \mathrm{VO}_{3}$ solutions [80]. The use of $\mathrm{N}_{2} / \mathrm{O}_{2}$ as the carrier gas led to a negligible deactivation, except for those catalysts with a higher microporosity, or a higher $\mathrm{SiO}_{2} / \mathrm{Al}_{2} \mathrm{O}_{3}$ molar ratio, which suffered a slight deactivation after $10 \mathrm{~h}$ of TOS. In all of the cases, strong Brönsted acid sites associated with the zeolite framework were responsible for glycerol conversion to acrolein, whereas vanadium species oxidized by a Mars-van Krevelen cycle using mobile lattice oxygen, where $\mathrm{V}^{5+}$ was partially reduced to $\mathrm{V}^{4+}$ [70]. With regard to the selectivity, in all of the cases, acrolein was the main product, reaching yields between $12.7-46.8 \%$, while acrylic acid was a minority product, obtaining a yield of $17.7 \%$ for V- $\beta$ zeolite in the best case. These data followed the same trend as that shown for Pestana et al. for the same catalyst under milder reaction conditions [81], and also were in agreement with data obtained for $\mathrm{V} / \mathrm{MFI}\left(\mathrm{SiO}_{2} / \mathrm{Al}_{2} \mathrm{O}_{3}=40\right)$ catalysts [70].

\subsection{Silicon-Aluminophosphate (SAPO)}

Aluminophosphates $\left(\mathrm{AlPO}_{4}-\mathrm{n}\right.$, where $\mathrm{n}$ denotes a structure type) were described by Wilson et al. in 1982 as a new class of zeolite-like molecular sieves [82]. These microporous materials are built up from a trick alternation of $\mathrm{AlO}_{4}$ and $\mathrm{PO}_{4}$ tetrahedra through corner sharing to form a neutral open framework. The neutrality of the $\mathrm{AlPO}_{4}$ structure limits its catalytic applications in dehydration reactions due to the absence of Brönsted acid sites. However, the substitution of phosphorus by silicon in the framework modifies the physicochemical properties, generating Brönsted acid sites [83], which are necessary for glycerol dehydration.

Several SAPOs (SAPO-11, SAPO-34, and SAPO-40) were evaluated in glycerol dehydration [84]. The catalytic results revealed a significant deactivation along the time-of-stream, being more pronounced in the case of SAPO-11 and SAPO-34 (Table 3). Lourenço et al. also indicated that the deactivation was directly related to the porous structure. The deactivation of SAPO-34 was more abrupt than that of SAPO-40 in spite of their similar microporous volume, due to the cage openings of SAPO-34 being much smaller than the pores of SAPO-40, leading to pore blocking by coke formation. In any case, the acrolein yield was higher than that previously reported by Chai et al. for SAPO-34 at short reaction times [18]. In the case of SAPO-11, an intermediate behavior was observed, since pore architecture influenced both the catalytic performance and the deactivation. Therefore, it seems clear that the porous network of solid acid catalysts had a strong influence on glycerol dehydration. Thus, for instance, SAPO-40, with a more open structure and a higher $S_{\text {BET }}$ value, proved to be highly resistant under the experimental conditions used, and it was regenerated without a loss of activity or significant structural damages.

Table 3. Catalytic activity of SAPO-11, SAPO-34, and SAPO-40 in glycerol dehydration.

\begin{tabular}{|c|c|c|c|c|c|c|}
\hline Catalyst & $\mathrm{T}\left({ }^{\circ} \mathrm{C}\right)$ & TOS (h) & $\mathrm{C}_{\text {gly }}(\%)$ & $Y_{\text {acrol }}(\%)$ & $\mathrm{Mmol}_{\mathrm{acrol}} \mathrm{h}^{-1} \mathrm{~g}_{\text {cat }}{ }^{-1}$ & Ref. \\
\hline \multirow[b]{2}{*}{ SAPO-11 } & \multirow[b]{2}{*}{350} & 2.5 & 100 & 73 & 2.4 & \multirow{6}{*}{ [84] } \\
\hline & & 120 & 26 & 19 & 0.6 & \\
\hline \multirow{2}{*}{ SAPO-34 } & \multirow{2}{*}{350} & 2.5 & 90 & 69 & 2.3 & \\
\hline & & 120 & 16 & 12 & 0.4 & \\
\hline \multirow{2}{*}{ SAPO-40 } & \multirow[b]{2}{*}{350} & 2.5 & 100 & 75 & 2.5 & \\
\hline & & 120 & 54 & 39 & 4.0 & \\
\hline SAPO-34 & 315 & 9 & 32 & 15 & 0.1 & [18] \\
\hline SAPO-11 & 280 & 1 & 88 & 55 & 0.9 & \multirow{2}{*}{ [25] } \\
\hline SAPO-34 & 280 & 1 & 59 & 42 & 0.7 & \\
\hline \multirow{2}{*}{ Meso-SAPO-40 } & 320 & 2.5 & 100 & 81 & 2.7 & \multirow{2}{*}{ [85] } \\
\hline & 320 & 120 & 87 & 68 & 2.3 & \\
\hline
\end{tabular}


Regarding the selectivity, SAPOs showed similar acrolein selectivity, about $75 \%$, and the presence of hydroxyacetone and acetaldehyde was also noteworthy (about $10 \%$ of selectivity) [84]. These data are in disagreement with those reported by Suprun et al., where the hydroxyacetone selectivity was higher [25]. They reported that SAPO-11 and SAPO-34 catalysts, with small micropores (5-6 $\mathrm{A})$, were less active but more selective than mesoporous $\mathrm{Al}_{2} \mathrm{O}_{3}-\mathrm{PO}_{4}$ and $\mathrm{TiO}_{2}-\mathrm{PO}$. Moreover, a detailed study with SAPO- 40 revealed that the use of high reaction temperatures $\left(\mathrm{T}>350^{\circ} \mathrm{C}\right)$ causes a drastic deactivation by the formation of carbonaceous deposits, although the catalyst can be easily regenerated, maintaining its catalytic performance $[84,85]$.

Recently, Fernandes et al. synthesized a mesoporous SAPO-40, using an organosilane as an additional porogen agent, replacing part of the silica source (Cab-OSil-M5) in the synthesis gel by [3-(trimethoxysilyl)propyl]-octadecyldimethyl-ammonium chloride, increasing the external surface area and mesopore volume [85]. In comparison to traditional SAPO-40, the long-term stability of mesoporous SAPO- 40 is notably higher, demonstrating the beneficial effect of mesoporosity. Thus, an increase in the pore volume diminishes the diffusional limitations caused by the blockage of the structure with carbonaceous deposits and facilitates the access to acid sites.

\subsection{Commercial Silica}

Generally, commercial silica displays a spherical morphology with high porosity, with a high specific surface area associated with interparticle voids. In spite of this porosity, the weak acidity of the silica is not enough to favor the glycerol dehydration to acrolein. Thus, $\mathrm{SiO}_{2}$ is usually employed as support or mixed with active oxides to disperse them instead of the active catalyst itself.

The morphology of the silica can be easily modulated in comparison to other oxides, which is an important parameter for attaining a suitable catalytic performance. Thus, Tsukuda et al. used a silica composed of spheres of $6 \mathrm{~nm}$ as support for several Keggin-type heteropolyacids (HPAs) (Table 4) [9]. These authors reported that all of the catalysts, except the catalyst with boric acid $\left(\mathrm{H}_{3} \mathrm{BO}_{3}\right)$ provided high values of glycerol conversion, although the acrolein yield differed between them. Generally, the main product was acrolein, although acetaldehyde and hydroxyacetone were also detected. Moreover, it is noteworthy that the silica impregnated with phosphomolybdic acid (Q6-PMo-30) reached lower acrolein yield values because of molybdenum triggers oxidation/reduction reactions, causing the formation of other products such as acetaldehyde. In all of the cases, the activity of the HPAs was higher in comparison to $\mathrm{SiO}_{2} / \mathrm{Al}_{2} \mathrm{O}_{3}$ and $\mathrm{H}_{3} \mathrm{PO}_{4} / \mathrm{SiO}_{2}$ due to the presence of stronger Brönsted acid sites associated with HPAs [86]. The highest catalytic activity in glycerol dehydration was found for the silica impregnated with silicotungstic acid, and it was ascribed to both the higher thermal stability $\left(500{ }^{\circ} \mathrm{C}\right)$ of this HPA and its strongest acidity in comparison to other HPAs [87].

In addition, Tsukuda chose this most active phase, the silicotungstic acid, to be supported in three silicas with different pore diameter $(3 \mathrm{~nm}, 6 \mathrm{~nm}$, and $10 \mathrm{~nm})$ [9]. The catalytic results revealed that the silica with a lower pore diameter was more susceptible to undergo deactivation at shorter reaction times in comparison to the silica with a pore diameter of $10 \mathrm{~nm}$. Therefore, they confirmed that the catalytic activity depended on both the nature of the heteropolyacid and the size of the mesopores of the silica support.

Considering the high activity of the silicotungstic acid $\left(\mathrm{H}_{4} \mathrm{SiW}_{12} \mathrm{O}_{40}\right)$, Kim et al. supported it on $\mathrm{SiO}_{2}-\mathrm{Al}_{2} \mathrm{O}_{3}$, but with a low percentage of $\mathrm{Al}\left(\mathrm{Si}_{0.9} \mathrm{Al}_{0.1} \mathrm{O}_{\mathrm{x}}\right)$ [88]. The highest acrolein yield was $54 \%$ after $2 \mathrm{~h}$ of TOS (Table 4 ). In this sense, it has been previously established that at low $\mathrm{Al}$ loadings, the aluminum can be incorporated into the silica framework under basic conditions [61], exhibiting physicochemical properties similar to those of zeolites, although lacking the microporous ordering. This fact was confirmed by $\mathrm{NH}_{3}-\mathrm{TPD}$, which revealed that the acidity was directly related to the catalytic behavior. Therefore, the presence of HSiW in supported catalysts increased the acidity, thus providing higher catalytic activities than those of the corresponding supports. Both glycerol conversion and acrolein yield significantly decreased with increasing time-on-stream due to carbonaceous species being deposited on the strong surface acid sites, provoking a loss of accessible 
active sites and decreasing the BET surface area and pore diameter, which complicated the diffusion of products.

Table 4. Catalytic activity of commercial silica-based catalysts for the glycerol dehydration reaction.

\begin{tabular}{|c|c|c|c|c|c|c|}
\hline Active Phase & $\mathrm{T}\left({ }^{\circ} \mathrm{C}\right)$ & TOS (h) & $\mathrm{C}_{\text {gly }}(\%)$ & $Y_{\text {acrol }}(\%)$ & $\mathrm{Mmol}_{\mathrm{acrol}} \mathrm{h}^{-1} \mathrm{~g}_{\mathrm{cat}}{ }^{-1}$ & Ref. \\
\hline $\mathrm{SiO}_{2}-\mathrm{H}_{3} \mathrm{PO}_{4}$ & 325 & 5 & 70 & 38 & 2.0 & \multirow{5}{*}{ [9] } \\
\hline $\mathrm{SiO}_{2}-\mathrm{H}_{3} \mathrm{BO}_{3}$ & 325 & 5 & 15 & 0.3 & 0.02 & \\
\hline $\mathrm{SiO}_{2}-\mathrm{PW}$ & 325 & 5 & 100 & 65 & 3.9 & \\
\hline $\mathrm{SiO}_{2}-\mathrm{PMo}$ & 325 & 5 & 98 & 33 & 2.0 & \\
\hline $\mathrm{SiO}_{2}-\mathrm{SiW}$ & 325 & 5 & 100 & 74 & 4.4 & \\
\hline $\mathrm{SiO}_{2}-\mathrm{SiW}$ & 315 & 2 & 23 & 6 & 13.1 & \multirow{3}{*}{ [88] } \\
\hline $\mathrm{Si}_{0.9} \mathrm{Al}_{0.1} \mathrm{O}_{\mathrm{x}}-\mathrm{SiW}$ & 315 & 2 & 97 & 54 & 127.3 & \\
\hline $\mathrm{Al}_{2} \mathrm{O}_{3}-\mathrm{SiW}$ & 315 & 2 & 87 & 33 & 26.1 & \\
\hline $\mathrm{SiO}_{2}-\mathrm{PW}$ & 275 & 10 & 16 & 4 & 78.3 & \multirow{3}{*}{ [40] } \\
\hline $\mathrm{Si}_{0.85} \mathrm{Al}_{0.15} \mathrm{O}_{\mathrm{x}}-\mathrm{PW}$ & 275 & 10 & 43 & 20 & 83.6 & \\
\hline $\mathrm{Al}_{2} \mathrm{O}_{3}-\mathrm{PW}$ & 275 & 10 & 13 & 3 & 13.0 & \\
\hline $\mathrm{S}_{\mathrm{i} 0.8} \mathrm{Al}_{0.2} \mathrm{O}_{\mathrm{x}}$ & 315 & 2 & 43 & 21 & 50.7 & [89] \\
\hline $\mathrm{SiO}_{2}-\mathrm{PW}$ & 315 & 10 & 20 & 11 & 3.3 & \multirow{2}{*}{ [90] } \\
\hline $\mathrm{ZrO}_{2}-\mathrm{PW}$ & 315 & 10 & 70 & 49 & 8.1 & \\
\hline $0.5 \mathrm{Nb}_{2} \mathrm{O}_{5} 0.5 \mathrm{WO}_{3} / \mathrm{SiO}_{2}$ & 305 & 1 & 99 & 47 & 0.4 & [30] \\
\hline $\mathrm{SiO}_{2} / \mathrm{WO}_{3} / \mathrm{ZrO}_{2}$ & 300 & 8 & 100 & 65 & 0.5 & [64] \\
\hline
\end{tabular}

Kang et al. carried out an analogous study using phosphotungstic acid $\left(\mathrm{H}_{3} \mathrm{PW}_{12} \mathrm{O}_{40}\right)$ supported on $\mathrm{SiO}_{2}-\mathrm{Al}_{2} \mathrm{O}_{3}$, obtaining similar results [40]. These authors pointed out that the incorporation of small amounts of $\mathrm{Al}$ increased the proportion of Brönsted acid sites, while the progressive addition of Al-species caused an increase of the Lewis acidity, which is not beneficial for the dehydration of glycerol to acrolein. In all of the cases, the mesoporous structure of supports was maintained after the incorporation of $\mathrm{H}_{3} \mathrm{PW}_{12} \mathrm{O}_{40}$.

Likewise, Kim et al. prepared $\mathrm{SiO}_{2}-\mathrm{Al}_{2} \mathrm{O}_{3}$ catalysts by the incorporation of $\mathrm{Al}^{3+}$ in basic medium [89], as was previously indicated for HPAs [40,88]. These authors also observed that a small amount of $\mathrm{Al}^{3+}$ could be incorporated into the silica structure generating Brönsted acid sites, which favored glycerol dehydration, whereas the Lewis acidity was associated with the extra-framework $\mathrm{Al}^{3+}$. Nonetheless, these values were below those obtained with HPAs under similar catalytic conditions [59], due to the HPAs displaying stronger Brönsted acid sites, which improved the catalytic performance in the dehydration of glycerol to acrolein.

In another study, Chai et al. also supported phosphotungstic acid on a commercial $\mathrm{SiO}_{2}$ and compared its catalytic behavior to $\mathrm{HPW} / \mathrm{ZrO}_{2}$ catalysts [90]. Despite the textural and acidic properties of $\mathrm{HPW} / \mathrm{SiO}_{2}$, the catalytic data showed that the acrolein yield was higher when $\mathrm{ZrO}_{2}$ was employed due to the stronger interaction between the $\mathrm{ZrO}_{2}$ and the Keggin anion (Table 4).

On the other hand, the silica can be mixed with other metal oxides with greater acid strength in order to increase the amount of available sites for glycerol dehydration. Massa et al. synthesized $\mathrm{WO}_{3}-\mathrm{Nb}_{2} \mathrm{O}_{5}$ supported on several oxides $\left(\mathrm{SiO}_{2}, \mathrm{TiO}_{2}\right.$ and $\left.\mathrm{Al}_{2} \mathrm{O}_{3}\right)$. However, the catalytic data showed that those catalysts supported on $\mathrm{SiO}_{2}$ reached the lowest acrolein yields $(47 \%$ for $0.5 \mathrm{WO}_{3}-0.5 \mathrm{Nb}_{2} \mathrm{O}_{5} / \mathrm{SiO}_{2}$ catalyst) (Table 4), probably because $\mathrm{SiO}_{2}$ is the support with the weakest acidity [30]. In all of the cases, acrolein and hydroxyacetone were obtained by the coexistence of Brönsted and Lewis acid sites; however, the main product was acrolein due to the transformation of the Lewis acid sites into pseudo-Brönsted acid sites by the presence of $\mathrm{H}_{2} \mathrm{O}$ in the reaction medium [39].

$\mathrm{Nb}_{2} \mathrm{O}_{5}$ supported on a commercial $\mathrm{SiO}_{2}$ was also evaluated in this reaction, obtaining the best results for the catalyst with a $20 \mathrm{wt} . \%$ of $\mathrm{Nb}_{2} \mathrm{O}_{5}$, which also displayed the highest acidity [91]. In addition, it was noteworthy that the most active catalyst in the first hours was more susceptible 
to suffer deactivation due to the faster formation of carbonaceous deposits. Several research works have reported the coexistence of Lewis and Brönsted sites in the $\mathrm{Nb}_{2} \mathrm{O}_{5}$ [92]. As has been previously mentioned, the Lewis acid sites interact with primary alcohols, favoring the formation of hydroxyacetone, while the interaction of secondary alcohols with Brönsted acid sites leads to acrolein (Figures 5 and 6) [39]. In addition, these authors established that Brönsted acid sites are also involved in intramolecular reactions, resulting in the formation of coke and consequently provoking the catalytic deactivation [92].

$\mathrm{WO}_{3} / \mathrm{ZrO}_{2}$ catalysts doped with silica were studied in glycerol dehydration. This tungstated zirconia contained both Brönsted and Lewis acid sites, so the main products are acrolein and hydroxyacetone [64]. It has been suggested that $\mathrm{H}^{\delta+}\left(\mathrm{WO}_{3}\right)_{\mathrm{n}}{ }^{\delta-}$ Brönsted acid sites were responsible for the selectivity toward acrolein $[64,93]$. Lauriol-Garbey et al. also reported that catalysts doped with silica showed to be more selective and stable catalysts, attaining full conversion and an acrolein yield of $65 \%$ after $8 \mathrm{~h}$ of TOS (Table 4) [64]. They affirmed that the deposition of $\mathrm{SiO}_{2}$ on $\mathrm{ZrO}_{2}$ favored the formation of larger mesopores and reduced the support basicity, minimizing the production of coke precursors, which was crucial to delay the deactivation of catalysts.

\section{Conclusions}

Different mesoporous materials have been evaluated as solid acid catalysts for glycerol dehydration to acrolein in order to overcome drawbacks associated with deactivation by coke formation. Porous silica-based catalysts, such as mesoporous silica, zeolites, silicon-aluminophosphates, and commercial silica have demonstrated that the presence of mesopores improved catalytic performance. In general, the existence of large pores increases the resistance to pore blocking, since the products diffusion is favored, decreasing the deactivation rate and providing a longer lifetime in the dehydration of glycerol. However, the deactivation of these materials finally took place by coke deposition, since the stability of these mesoporous silicon-based catalysts during their regeneration by thermal treatment was important. Therefore, both the pore size and density of acid sites played an important role in the catalytic performance and deactivation rates, as they were crucial to the control of these parameters to maximize acrolein production.

Author Contributions: Conceptualization, P.M.-T. devised the elaboration of this review. Data curation, J.A.C., C.P.J.-G. and R.M.-T. collected the data reported in the literature previously. Funding adquisition, P.M.-T. obtained the funds coming from the project CTQ2015-64226-C3-3-R. Investigation, J.A.C., C.G.-S. and C.P.J.-G. selected the data of previous research. Project administration, R.M.-T. and C.G.-S. coordinated the research. Supervision, P.M.-T. and R.M.-T. planned the core of the present research. Writing-original draft, J.A.C. wrote the first draft of the present manuscript. Writing-review \& editing, C.G.-S., R.M.-T. and P.M.-T. revised and completed the first draft.

Funding: This research was funded by the Ministry of Economy and Competitiveness (Spain), grant numbers (CTQ2015-64226-C3-3-R, IEDI-2016-00743), Junta de Andalucía (Spain) (P12-RNM-1565), and FEDER (European Union) funds.

Acknowledgments: J.A.C. and C.G.-S. thank to the Malaga University for the financial support.

Conflicts of Interest: The authors declare no conflicts of interest.

\section{References}

1. Klass, D.L. Biomass for Renewable Energy, Fuels and Chemicals; Academic Press: Cambridge, MA, USA, 1998.

2. European Parliament and of the Council. Directive 2003/30/EC of the European Parliament and of the Council of 05/08/2003 on the Promotion of the Use of Biofuels or Other Renewable Fuels for Transport; European Parliament and of the Council: Luxembourg, 2003.

3. Ong, H.; Mahlia, T.; Masjuki, H.; Norhasyima, R. Comparison of palm oil, jatropha curcas and calophyllum inophyllum for biodiesel: A review. Renew. Sustain. Energy Rev. 2011, 15, 3501-3515. [CrossRef]

4. Talebian-Kiakalaieh, A.; Amin, N.; Zarei, A.; Noshadi, I. Transesterification of waste cooking oil by heteropoly acid (HPA) catalyst: Optimization and kinetic model. Appl. Energy 2013, 102, 283-292. [CrossRef] 
5. Tan, H.; Aziz, A.; Aroua, M. Glycerol production and its applications as a raw material: A review. Renew. Sustain. Energy Rev. 2013, 27, 118-127. [CrossRef]

6. Ciriminna, R.; Della Pina, C.; Rossi, M.; Pagliaro, M. Understanding the glycerol market. Eur. J. Lipid Sci. Technol. 2014, 116, 1432-1439. [CrossRef]

7. Organisation for Economic Co-Operation and Development/Food and Agriculture Organization of the United Nations (OECD-FAO) Agricultural Outlook 2017-2026. Available online: http://dx.Doi.Org/10. 1787/agr_outlook-2017-en (accessed on 21 February 2018).

8. Katryniok, B.; Paul, S.; Belliere-Baca, V.; Rey, P.; Dumeignil, F. Glycerol dehydration to acrolein in the context of new uses of glycerol. Green Chem. 2010, 12, 2079-2098. [CrossRef]

9. Tsukuda, E.; Sato, S.; Takahashi, R.; Sodesawa, T. Production of acrolein from glycerol over silica-supported heteropoly acids. Catal. Commun. 2007, 8, 1349-1353. [CrossRef]

10. Pathak, K.; Reddy, K.; Bakhshi, N.; Dalai, A. Catalytic conversion of glycerol to value added liquid products. Appl. Catal. A Gen. 2010, 372, 224-238. [CrossRef]

11. Werpy, T.; Petersen, G. Top Value-Added Chemicals from Biomass; US Department of Energy (USDOE): Washington, DC, USA, 2004; Volume 1.

12. Zhou, C.; Zhao, H.; Tong, D.; Wu, L.; Yu, W. Recent advances in catalytic conversion of glycerol. Catal. Rev. 2013, 55, 369-453. [CrossRef]

13. Anitha, M.; Kamarudin, S.; Kofli, N. The potential of glycerol as a value-added commodity. Chem. Eng. J. 2016, 295, 119-130. [CrossRef]

14. Pagliaro, M.; Ciriminna, R.; Kimura, H.; Rossi, M.; Della Pina, C. From glycerol to value-added products. Angew. Chem. Int. Ed. 2007, 46, 4434-4440. [CrossRef] [PubMed]

15. Liu, L.; Ye, X.; Bozell, J. A comparative review of petroleum-based and bio-based acrolein production. ChemSusChem 2012, 5, 1162-1180. [CrossRef] [PubMed]

16. Katryniok, B.; Paul, S.; Capron, M.; Dumeignil, F. Towards the sustainable production of acrolein by glycerol dehydration. ChemSusChem 2009, 2, 719-730. [CrossRef] [PubMed]

17. Pagliaro, M.; Rossi, M. The Future of Glycerol: New Uses of a Versatile Raw Material; RSC Publishing: Cambridge, UK, 2008.

18. Chai, S.; Wang, H.; Liang, Y.; Xu, B. Sustainable production of acrolein: Investigation of solid acid-base catalysts for gas-phase dehydration of glycerol. Green Chem. 2007, 9, 1130-1136. [CrossRef]

19. Tao, L.; Yan, B.; Liang, Y.; Xu, B. Sustainable production of acrolein: Catalytic performance of hydrated tantalum oxides for gas-phase dehydration of glycerol. Green Chem. 2013, 15, 696-705. [CrossRef]

20. Tao, L.; Chai, S.; Zuo, Y.; Zheng, W.; Liang, Y.; Xu, B. Sustainable production of acrolein: Acidic binary metal oxide catalysts for gas-phase dehydration of glycerol. Catal. Today 2010, 158, 310-316. [CrossRef]

21. Gu, Y.; Liu, S.; Li, C.; Cui, Q. Selective conversion of glycerol to acrolein over supported nickel sulfate catalysts. J. Catal. 2013, 301, 93-102. [CrossRef]

22. Cavani, F.; Guidetti, S.; Marinelli, L.; Piccinini, M.; Ghedini, E.; Signoretto, M. The control of selectivity in gas-phase glycerol dehydration to acrolein catalysed by sulfated zirconia. Appl. Catal. B Environ. 2010, 100, 197-204. [CrossRef]

23. Wang, F.; Dubois, J.; Ueda, W. Catalytic dehydration of glycerol over vanadium phosphate oxides in the presence of molecular oxygen. J. Catal. 2009, 268, 260-267. [CrossRef]

24. Stosic, D.; Bennici, S.; Sirotin, S.; Calais, C.; Couturier, J.; Dubois, J.; Travert, A.; Auroux, A. Glycerol dehydration over calcium phosphate catalysts: Effect of acidic-basic features on catalytic performance. Appl. Catal. A Gen. 2012, 447, 124-134. [CrossRef]

25. Suprun, W.; Lutecki, M.; Haber, T.; Papp, H. Acidic catalysts for the dehydration of glycerol: Activity and deactivation. J. Mol. Catal. A Chem. 2009, 309, 71-78. [CrossRef]

26. Lauriol-Garbey, P.; Postole, G.; Loridant, S.; Auroux, A.; Belliere-Baca, V.; Rey, P.; Millet, J. Acid-base properties of niobium-zirconium mixed oxide catalysts for glycerol dehydration by calorimetric and catalytic investigation. Appl. Catal. B Environ. 2011, 106, 94-102. [CrossRef]

27. Lauriol-Garbay, P.; Millet, J.; Loridant, S.; Belliere-Baca, V.; Rey, P. New efficient and long-life catalyst for gas-phase glycerol dehydration to acrolein. J. Catal. 2011, 280, 68-76. [CrossRef]

28. Massa, M.; Andersson, A.; Finocchio, E.; Busca, G.; Lenrick, F.; Wallenberg, L. Performance of $\mathrm{ZrO}_{2}$-supported $\mathrm{Nb}$ - and $\mathrm{W}$-oxide in the gas-phase dehydration of glycerol to acrolein. J. Catal. 2013, 297, 93-109. [CrossRef] 
29. Chai, S.; Yan, B.; Tao, L.; Liang, Y.; Xu, B. Sustainable production of acrolein: Catalytic gas-phase dehydration of glycerol over dispersed tungsten oxides on alumina, zirconia and silica. Catal. Today 2014, 234, 215-222. [CrossRef]

30. Massa, M.; Andersson, A.; Finocchio, E.; Busca, G. Gas-phase dehydration of glycerol to acrolein over $\mathrm{Al}_{2} \mathrm{O}_{3}{ }^{-}, \mathrm{SiO}_{2}{ }^{-}$, and $\mathrm{TiO}_{2}$-supported $\mathrm{Nb}$ - and $\mathrm{W}$-oxide catalysts. J. Catal. 2013, 307, 170-184. [CrossRef]

31. Ulgen, A.; Hoelderich, W. Conversion of glycerol to acrolein in the presence of $\mathrm{WO}_{3} / \mathrm{ZrO}_{2}$ catalysts. Catal. Lett. 2009, 131, 122-128. [CrossRef]

32. Kim, Y.; Jung, K.; Park, E. Gas-phase dehydration of glycerol over ZSM-5 catalysts. Microporous Mesoporous Mater. 2010, 131, 28-36. [CrossRef]

33. Jia, C.; Liu, Y.; Schmidt, W.; Lu, A.; Schuth, F. Small-sized HZSM-5 zeolite as highly active catalyst for gas phase dehydration of glycerol to acrolein. J. Catal. 2010, 269, 71-79. [CrossRef]

34. Kim, Y.; Jung, K.; Park, E. A comparative study for gas-phase dehydration of glycerol over H-zeolites. Appl. Catal. A Gen. 2011, 393, 275-287. [CrossRef]

35. Omata, K.; Izumi, S.; Murayama, T.; Ueda, W. Hydrothermal synthesis of W-Nb complex metal oxides and their application to catalytic dehydration of glycerol to acrolein. Catal. Today 2013, 201, 7-11. [CrossRef]

36. Oliveira, L.; Portilho, M.; Silva, A.; Taroco, H.; Souza, P. Modified niobia as a bifunctional catalyst for simultaneous dehydration and oxidation of glycerol. Appl. Catal. B Environ. 2012, 117, 29-35. [CrossRef]

37. Martin, A.; Armbruster, U.; Atia, H. Recent developments in dehydration of glycerol toward acrolein over heteropolyacids. Eur. J. Lipid Sci. Technol. 2012, 114, 10-23. [CrossRef]

38. Atia, H.; Armbruster, U.; Martin, A. Dehydration of glycerol in gas phase using heteropolyacid catalysts as active compounds. J. Catal. 2008, 258, 71-82. [CrossRef]

39. Alhanash, A.; Kozhevnikova, E.; Kozhevnikov, I. Gas-phase dehydration of glycerol to acrolein catalysed by caesium heteropoly salt. Appl. Catal. A Gen. 2010, 378, 11-18. [CrossRef]

40. Kang, T.; Choi, J.; Bang, Y.; Yoo, J.; Song, J.; Joe, W.; Choi, J.; Song, I. Dehydration of glycerin to acrolein over $\mathrm{H}_{3} \mathrm{PW}_{12} \mathrm{O}_{40}$ heteropolyacid catalyst supported on silica-alumina. J. Mol. Catal. A Chem. 2015, 396, 282-289. [CrossRef]

41. Laino, T.; Tuma, C.; Curioni, A.; Jochnowitz, E.; Stolz, S. A revisited picture of the mechanism of glycerol dehydration. J. Phys. Chem. A 2011, 115, 3592-3595. [CrossRef] [PubMed]

42. Kresge, C.; Leonowicz, M.; Roth, W.; Vartuli, J.; Beck, J. Ordered mesoporous molecular-sieves synthesized by a liquid-crystal template mechanism. Nature 1992, 359, 710-712. [CrossRef]

43. Zhao, D.; Feng, J.; Huo, Q.; Melosh, N.; Fredrickson, G.; Chmelka, B.; Stucky, G. Triblock copolymer syntheses of mesoporous silica with periodic 50 to 300 angstrom pores. Science 1998, 279, 548-552. [CrossRef] [PubMed]

44. Lourenco, J.; Macedo, M.; Fernandes, A. Sulfonic-functionalized SBA-15 as an active catalyst for the gas-phase dehydration of glycerol. Catal. Commun. 2012, 19, 105-109. [CrossRef]

45. Dalla Costa, B.O.; Legnoverde, M.; Lago, C.; Decolatti, H.; Querini, C. Sulfonic functionalized SBA-15 catalysts in the gas phase glycerol dehydration. Thermal stability and catalyst deactivation. Microporous Mesoporous Mater. 2016, 230, 66-75. [CrossRef]

46. Ma, T.; Ding, J.; Shao, R.; Yun, Z. Catalytic conversion of glycerol to acrolein over MCM-41 by the grafting of phosphorus species. Can. J. Chem. Eng. 2016, 94, 924-930. [CrossRef]

47. Kobayashi, H.; Ito, S.; Hara, K.; Fukuoka, A. Conversion of glycerol to acrolein by mesoporous sulfated zirconia-silica catalyst. Chin. J. Catal. 2017, 38, 420-425. [CrossRef]

48. Ding, J.; Ma, T.; Yun, Z.; Shao, R. Heteropolyacid $\left(\mathrm{H}_{3} \mathrm{PW}_{12} \mathrm{O}_{40}\right)$ supported MCM-41: An effective solid acid catalyst for the dehydration of glycerol to acrolein. J. Wuhan Univ. Technol. 2017, 32, 1511-1516. [CrossRef]

49. Ma, T.; Ding, J.; Shao, R.; Xu, W.; Yun, Z. Dehydration of glycerol to acrolein over wells-dawson and keggin type phosphotungstic acids supported on MCM-41 catalysts. Chem. Eng. J. 2017, 316, 797-806. [CrossRef]

50. Liu, R.; Wang, T.; Jin, Y. Catalytic dehydration of glycerol to acrolein over HPW supported on $\mathrm{Cs}^{+}$modified SBA-15. Catal. Today 2014, 233, 127-132. [CrossRef]

51. Liu, R.; Lyu, S.; Wang, T. Sustainable production of acrolein from biodiesel-derived crude glycerol over $\mathrm{H}_{3} \mathrm{PW}_{12} \mathrm{O}_{40}$ supported on Cs-modified SBA-15. J. Ind. Eng. Chem. 2016, 37, 354-360. [CrossRef]

52. Ma, T.; Yun, Z.; Xu, W.; Chen, L.; Li, L.; Ding, J.; Shao, R. Pd- $\mathrm{H}_{3} \mathrm{PW}_{12} \mathrm{O}_{40} / \mathrm{Zr}-\mathrm{MCM}-41$ : An efficient catalyst for the sustainable dehydration of glycerol to acrolein. Chem. Eng. J. 2016, 294, 343-352. [CrossRef]

53. Trakarnpruk, W. Platinum/phosphotungstic acid/(Zr)MCM-41 catalysts in glycerol dehydration. Mendeleev Commun. 2014, 24, 167-169. [CrossRef] 
54. Viswanadham, B.; Srikanth, A.; Kumar, V.; Chary, K. Vapor phase dehydration of glycerol to acrolein over SBA-15 supported vanadium substituted phosphomolybdic acid catalyst. J. Nanosci. Nanotechnol. 2015, 15, 5391-5402. [CrossRef] [PubMed]

55. Garcia-Sancho, C.; Moreno-Tost, R.; Merida-Robles, J.; Santamaria-Gonzalez, J.; Jimenez-Lopez, A.; Maireles-Torres, P. Zirconium doped mesoporous silica catalysts for dehydration of glycerol to high added-value products. Appl. Catal. A Gen. 2012, 433, 179-187. [CrossRef]

56. Katryniok, B.; Paul, S.; Capron, M.; Lancelot, C.; Belliere-Baca, V.; Rey, P.; Dumeignil, F. A long-life catalyst for glycerol dehydration to acrolein. Green Chem. 2010, 12, 1922-1925. [CrossRef]

57. Cecilia, J.A.; García-Sancho, C.; Mérida-Robles, J.M.; Santamaría-González, J.; Moreno-Tost, R.; Maireles-Torres, P. V and V-P containing Zr-SBA-15 catalysts for dehydration of glycerol to acrolein. Catal. Today 2015, 254, 43-52. [CrossRef]

58. García-Sancho, C.; Cecilia, J.A.; Moreno-Ruiz, A.; Mérida-Robles, J.M.; Santamaría-González, J.; Moreno-Tost, R.; Maireles-Torres, P. Influence of the niobium supported species on the catalytic dehydration of glycerol to acrolein. Appl. Catal. B Environ. 2015, 179, 139-149. [CrossRef]

59. Cecilia, J.; Garcia-Sancho, C.; Merida-Robles, J.; Gonzalez, J.; Moreno-Tost, R.; Maireles-Torres, P. $\mathrm{WO}_{3}$ supported on Zr doped mesoporous SBA-15 silica for glycerol dehydration to acrolein. Appl. Catal. A Gen. 2016, 516, 30-40. [CrossRef]

60. Garcia-Sancho, C.; Cecilia, J.; Merida-Robles, J.; Gonzalez, J.; Moreno-Tost, R.; Infantes-Molina, A.; Maireles-Torres, P. Effect of the treatment with $\mathrm{H}_{3} \mathrm{PO}_{4}$ on the catalytic activity of $\mathrm{Nb}_{2} \mathrm{O}_{5}$ supported on Zr-doped mesoporous silica catalyst. Case study: Glycerol dehydration. Appl. Catal. B Environ. 2018, 221, 158-168. [CrossRef]

61. Cecilia, J.; Garcia-Sancho, C.; Merida-Robles, J.; Santamaria-Gonzalez, J.; Infantes-Molina, A.; Moreno-Tost, R.; Maireles-Torres, P. Aluminum doped mesoporous silica SBA-15 for glycerol dehydration to value-added chemicals. J. Sol-Gel Sci. Technol. 2017, 83, 342-354. [CrossRef]

62. Salas, P.; Wang, J.; Armendariz, H.; Angeles-Chavez, C.; Chen, L. Effect of the Si/Zr molar ratio on the synthesis of Zr-based mesoporous molecular sieves. Mater. Chem. Phys. 2009, 114, 139-144. [CrossRef]

63. Anderson, J.; Fergusson, C.; Rodriguez-Ramos, I.; Guerrero-Ruiz, A. Influence of Si/Zr ratio on the formation of surface acidity in silica-zirconia aerogels. J. Catal. 2000, 192, 344-354. [CrossRef]

64. Lauriol-Garbey, P.; Loridant, S.; Belliere-Baca, V.; Rey, P.; Millet, J. Gas phase dehydration of glycerol to acrolein over $\mathrm{WO}_{3} / \mathrm{ZrO}_{2}$ catalysts: Improvement of selectivity and stability by doping with $\mathrm{SiO}_{2}$. Catal. Commun. 2011, 16, 170-174. [CrossRef]

65. Katryniok, B.; Paul, S.; Capron, M.; Belliere-Baca, V.; Rey, P.; Dumeignil, F. Regeneration of silica-supported silicotungstic acid as a catalyst for the dehydration of glycerol. ChemSusChem 2012, 5, 1298-1306. [CrossRef] [PubMed]

66. Carrico, C.; Cruz, F.; Santos, M.; Pastore, H.; Andrade, H.; Mascarenhas, A. Efficiency of zeolite MCM-22 with different $\mathrm{SiO}_{2} / \mathrm{Al}_{2} \mathrm{O}_{3}$ molar ratios in gas phase glycerol dehydration to acrolein. Microporous Mesoporous Mater. 2013, 181, 74-82. [CrossRef]

67. Choi, Y.; Park, H.; Yun, Y.; Yi, J. Effects of catalyst pore structure and acid properties on the dehydration of glycerol. ChemSusChem 2015, 8, 974-979. [CrossRef] [PubMed]

68. Rodrigues, M.; Vignatti, C.; Garetto, T.; Pulcinelli, S.; Santilli, C.; Martins, L. Glycerol dehydration catalyzed by MWW zeolites and the changes in the catalyst deactivation caused by porosity modification. Appl. Catal. A Gen. 2015, 495, 84-91. [CrossRef]

69. Gu, Y.; Cui, N.; Yu, Q.; Li, C.; Cui, Q. Study on the influence of channel structure properties in the dehydration of glycerol to acrolein over H-zeolite catalysts. Appl. Catal. A Gen. 2012, 429, 9-16. [CrossRef]

70. Possato, L.; Cassinelli, W.; Garetto, T.; Pulcinelli, S.; Santilli, C.; Martins, L. One-step glycerol oxidehydration to acrylic acid on multifunctional zeolite catalysts. Appl. Catal. A Gen. 2015, 492, 243-251. [CrossRef]

71. Decolatti, H.P.; Dalla Costa, B.O.; Querini, C.A. Dehydration of glycerol to acrolein using H-ZSM5 zeolite modified by alkali treatment with Naoh. Microporous Mesoporous Mater. 2015, 204, 180-189. [CrossRef]

72. Possato, L.; Diniz, R.; Garetto, T.; Pulcinelli, S.; Santilli, C.; Martins, L. A comparative study of glycerol dehydration catalyzed by micro/mesoporous MFI zeolites. J. Catal. 2013, 300, 102-112. [CrossRef]

73. Wang, Z.; Wang, L.; Jiang, Y.; Hunger, M.; Huang, J. Cooperativity of Brönsted and Lewis acid sites on zeolite for glycerol dehydration. ACS Catal. 2014, 4, 1144-1147. [CrossRef] 
74. Lari, G.; Chen, Z.; Mondelli, C.; Perez-Ramirez, J. Bifunctional hierarchical zeolite-supported silver catalysts for the conversion of glycerol to allyl alcohol. Chem CatChem 2017, 9, 2195-2202. [CrossRef]

75. Zhang, H.; Hu, Z.; Huang, L.; Zhang, H.; Song, K.; Wang, L.; Shi, Z.; Ma, J.; Zhuang, Y.; Shen, W.; et al. Dehydration of glycerol to acrolein over hierarchical zsm-5 zeolites: Effects of mesoporosity and acidity. ACS Catal. 2015, 5, 2548-2558. [CrossRef]

76. Beerthuis, R.; Huang, L.; Shiju, N.; Rothenberg, G.; Shen, W.; Xu, H. Facile synthesis of a novel hierarchical ZSM-5 zeolite: A stable acid catalyst for dehydrating glycerol to acrolein. ChemCatChem 2018, 10, 211-221. [CrossRef] [PubMed]

77. Huang, L.; Qin, F.; Huang, Z.; Zhuang, Y.; Ma, J.; Xu, H.; Shen, W. Hierarchical ZSM-5 zeolite synthesized by an ultrasound-assisted method as a long-life catalyst for dehydration of glycerol to acrolein. Ind. Eng. Chem. Res. 2016, 55, 7318-7327. [CrossRef]

78. Dos Santos, M.; Andrade, H.; Mascarenhas, A. Reduced coke formation during the gas phase oxidative dehydration of glycerol over ferrierite zeolites synthesized in fluoride medium. Microporous Mesoporous Mater. 2016, 223, 105-113. [CrossRef]

79. Viswanadham, B.; Nagaraju, N.; Rohitha, C.; Vishwanathan, V.; Chary, K. Synthesis, characterization and catalytic dehydration of glycerol to acrolein over phosphotungstic acid supported Y-zeolite catalysts. Catal. Lett. 2018, 148, 397-406. [CrossRef]

80. Silva, T.; dos Santos, M.; Santiago, A.; Santana, D.; Cruz, F.; Andrade, H.; Mascarenhas, A. Gas phase glycerol oxidative dehydration over bifunctional V/H-zeolite catalysts with different zeolite topologies. Catal. Today 2017, 289, 38-46. [CrossRef]

81. Pestana, C.; Guerra, A.; Ferreira, G.; Turci, C.; Mota, C. Oxidative dehydration of glycerol to acrylic acid over vanadium-impregnated zeolite beta. J. Braz. Chem. Soc. 2013, 24, 100-105. [CrossRef]

82. Wilson, S.; Lok, B.; Messina, C.; Cannan, T.; Flanigen, E. Aluminophosphate molecular-sieves. A new class of microporous crystalline inorganic solids. J. Am. Chem. Soc. 1982, 104, 1146-1147. [CrossRef]

83. Sastre, G.; Lewis, D.; Catlow, C. Mechanisms of silicon incorporation in aluminophosphate molecular sieves. J. Mol. Catal. A Chem. 1997, 119, 349-356. [CrossRef]

84. Lourenco, J.; Fernandes, A.; Bertolo, R.; Ribeiro, M. Gas-phase dehydration of glycerol over thermallystable sapo-40 catalyst. RSC Adv. 2015, 5, 10667-10674. [CrossRef]

85. Fernandes, A.; Filipa Ribeiro, M.; Lourenço, J.P. Gas-phase dehydration of glycerol over hierarchical silicoaluminophosphate sapo-40. Catal. Commun. 2017, 95, 16-20. [CrossRef]

86. Kozhevnikov, I. Catalysis by heteropolyacids and multicomponent polyoxometalates in liquid-phase reactions. Chem. Rev. 1998, 98, 171-198. [CrossRef] [PubMed]

87. Thomas, A.; Dablemont, C.; Basset, J.; Lefebvre, F. Comparison of $\mathrm{H}_{3} \mathrm{PW}_{12} \mathrm{O}_{40}$ and $\mathrm{H}_{4} \mathrm{SiW}_{12} \mathrm{O}_{40}$ heteropolyacids supported on silica by h-1 mas nmr. C. R. Chim. 2005, 8, 1969-1974. [CrossRef]

88. Kim, Y.; You, S.; Jung, K.; Park, E. Effect of al content on the gas-phase dehydration of glycerol over silica-alumina-supported silicotungstic acid catalysts. Bull. Korean Chem. Soc. 2012, 33, 2369-2377. [CrossRef]

89. Kim, Y.; Jung, K.; Park, E. Gas-phase dehydration of glycerol over silica-alumina catalysts. Appl. Catal. B Environ. 2011, 107, 177-187. [CrossRef]

90. Chai, S.; Wang, H.; Liang, Y.; Xu, B. Sustainable production of acrolein: Gas-phase dehydration of glycerol over 12-tungstophosphoric acid supported on $\mathrm{ZrO}_{2}$ and $\mathrm{SiO}_{2}$. Green Chem. 2008, 10, 1087-1093. [CrossRef]

91. Shiju, N.; Brown, D.; Wilson, K.; Rothenberg, G. Glycerol valorization: Dehydration to acrolein over silica-supported niobia catalysts. Top. Catal. 2010, 53, 1217-1223. [CrossRef]

92. Foo, G.; Wei, D.; Sholl, D.; Sievers, C. Role of Lewis and Brönsted acid sites in the dehydration of glycerol over niobia. ACS Catal. 2014, 4, 3180-3192. [CrossRef]

93. Baertsch, C.; Komala, K.; Chua, Y.; Iglesia, E. Genesis of Brönsted acid sites during dehydration of 2-butanol on tungsten oxide catalysts. J. Catal. 2002, 205, 44-57. [CrossRef]

(C) 2018 by the authors. Licensee MDPI, Basel, Switzerland. This article is an open access article distributed under the terms and conditions of the Creative Commons Attribution (CC BY) license (http:/ / creativecommons.org/licenses/by/4.0/). 